\title{
Effect of Support Redox Character on Catalytic Performance in the Gas Phase Hydrogenation of Benzaldehyde and Nitrobenzene over Supported Gold
}

Maoshuai Li, Xiaodong Wang, Fernando Cárdenas-Lizana* and Mark A. Keane

Chemical Engineering, School of Engineering and Physical Sciences, Heriot-Watt University, Edinburgh EH14 4AS, Scotland

*corresponding author

Tel: +44(0)131 451 4115, e-mail: f.cardenaslizana @hw.ac.uk 


\begin{abstract}
A range of oxides $\left(\gamma-\mathrm{Al}_{2} \mathrm{O}_{3}, \mathrm{TiO}_{2}, \mathrm{ZrO}_{2}, \mathrm{CeO}_{2}, \alpha-\mathrm{Fe}_{2} \mathrm{O}_{3}\right.$ and $\left.\mathrm{Fe}_{3} \mathrm{O}_{4}\right)$ with different redox properties were used to support nano-scale (mean $=2-8 \mathrm{~nm}$ ) Au and employed in the gas phase hydrogenation of benzaldehyde and nitrobenzene. The catalysts were subjected to TPR, $\mathrm{H}_{2} / \mathrm{O}_{2}$ titration, $\mathrm{H}_{2}$ TPD, XRD, TEM/STEM and XPS analysis. The supported Au phase promoted partial reduction of the reducible supports through the action of spillover hydrogen (based on TPD), which generated surface oxygen vacancies (demonstrated by $\mathrm{O}_{2}$ titration) that inhibit $\mathrm{Au}$ particle sintering during catalyst activation. Electron transfer to generate charged Au species (determined by XPS) correlates with support ionisation potential. Higher nitrobenzene hydrogenation (to aniline) TOFs were recorded relative to benzaldehyde where rate increased with decreasing $\mathrm{Au}$ size (from 8 to $4 \mathrm{~nm}$ ) with measurably lower TOF over $\mathrm{Au}$ $<3 \mathrm{~nm}$. Strong binding of $-\mathrm{CH}=\mathrm{O}$ and $-\mathrm{NO}_{2}$ functions to oxygen vacancies resulted in lower hydrogenation rates. Higher temperatures $(>413 \mathrm{~K})$ promoted benzaldehyde hydrogenolysis to toluene and benzene. The formation of $\mathrm{Au}^{\delta-}$ on non-reducible $\mathrm{Al}_{2} \mathrm{O}_{3}$ favoured selective reduction of $-\mathrm{CH}=\mathrm{O}$ with full selectivity to benzyl alcohol at $413 \mathrm{~K}$.
\end{abstract}

Keywords: Selective hydrogenation; benzaldehyde; nitrobenzene; reducible supports; oxygen vacancies; Au particle size effect. 


\section{Introduction}

The selective hydrogenation of benzaldehyde to benzyl alcohol and nitrobenzene to aniline are important in the production of herbicides, dyes, pigments and fine chemicals $[1,2]$. Conventional batch synthesis delivers low product yields, is energy inefficient and generates significant waste where exclusive reduction of the carbonyl and nitro group is challenging [3]. Continuous gas phase reaction presents a number of advantages including ease of product/catalyst separation and reduced downtime [4]. Supported Au at the nano-scale $(<10$ $\mathrm{nm}$ ) exhibits unique selectivity in the hydrogenation of multi-functional reactants although activity is lower compared with conventional transition metals (Pt, $\mathrm{Ru}, \mathrm{Pd}$ and $\mathrm{Ni}$ ) [5] due to the limited capacity of $\mathrm{Au}$ to chemisorb/dissociate $\mathrm{H}_{2}$ [6]. Studies to date on the catalytic hydrogenation of carbonyl (acrolein, benzalacetone, cinnamaldehyde and crotonaldehyde) [7,8] and nitro (chloronitrobenzene, nitrostyrene and nitrobenzaldehyde) [9,10] compounds have shown a dependence on the electronic and geometric properties of the Au phase that are influenced by the support. Smaller Au particles are formed on reducible oxides $\left(e . g . \mathrm{TiO}_{2}\right.$ and $\mathrm{CeO}_{2}$ ) relative to non-reducible $\mathrm{ZrO}_{2}$ and $\mathrm{SiO}_{2}[11,12]$. Higher turnover frequencies (TOF) with decreasing Au size (2-9 nm) has been reported in the hydrogenation of crotonaldehyde $[11,13]$ and nitrobenzene [14] for $\mathrm{Au}$ supported on $\mathrm{TiO}_{2}, \mathrm{Al}_{2} \mathrm{O}_{3}$ and $\mathrm{SiO}_{2}$. Okumura et al. [11] observed higher alcohol selectivity (from crotonaldehyde) over $\mathrm{Au} / \mathrm{TiO}_{2}$ than $\mathrm{Au} / \mathrm{Al}_{2} \mathrm{O}_{3}$ and $\mathrm{Au} / \mathrm{SiO}_{2}$. Milone and co-workers [15] proposed that reducible iron oxides promote the formation of electron-rich $\mathrm{Au}$ through metal-support electron transfer that favours $-\mathrm{CH}=\mathrm{O}$ reduction. Rojas et al. [16] concluded that negatively charged $\mathrm{Au}$ (on $\mathrm{SiO}_{2}$ ) binds the electrophilic carbon in $-\mathrm{CH}=\mathrm{O}$ facilitating hydrogenation of cinnamaldehyde and benzalacetone.

In nitro group reduction, the high selectivity exhibited by $\mathrm{Au} / \mathrm{TiO}_{2}$ has been attributed to metal-support synergy that promotes $-\mathrm{NO}_{2}$ activation [17]. Shimizu et al. [18] considered the 
role of $\mathrm{Al}_{2} \mathrm{O}_{3}$ acidity/basicity in tandem with coordinatively unsaturated $\mathrm{Au}$ to dissociate $\mathrm{H}_{2}$ to $\mathrm{H}^{+} / \mathrm{H}^{-}$at the metal/support interface and selectively reduce $-\mathrm{NO}_{2}$ in the presence of other reactive functionalities. In the hydrogenation of $p$-chloronitrobenzene unwanted hydrodechlorination was reported for $\mathrm{Au} / \mathrm{Ce}_{0.62} \mathrm{Zr}_{0.38} \mathrm{O}_{2}$ and ascribed to $\mathrm{C}-\mathrm{Cl}$ scission at oxygen vacancy sites [19]. Selective hydrogenation has been well established for Au catalysts but the contribution of the support in modifying Au structure, reactant activation and overall surface reaction mechanism is far from resolved. In this study we compare the catalytic action of $\mathrm{Au}$ nanoparticles on oxides $\left(\gamma-\mathrm{Al}_{2} \mathrm{O}_{3}, \mathrm{ZrO}_{2}, \mathrm{TiO}_{2}, \mathrm{CeO}_{2}, \alpha-\mathrm{Fe}_{2} \mathrm{O}_{3}\right.$ and $\left.\mathrm{Fe}_{3} \mathrm{O}_{4}\right)$ with distinct redox character in the hydrogenation of $-\mathrm{CH}=\mathrm{O}$ (benzaldehyde) and $-\mathrm{NO}_{2}$ (nitrobenzene) and correlate performance with catalyst structure. We propose surface reaction mechanisms to account for the role of support reducibility in governing $-\mathrm{CH}=\mathrm{O}$ and $-\mathrm{NO}_{2}$ activation and product selectivity.

\section{Experimental}

\subsection{Catalyst preparation and activation}

The supports employed in this study were obtained from commercial sources $\left(\gamma-\mathrm{Al}_{2} \mathrm{O}_{3}\right.$ (Puralox, Condea Vista), $\mathrm{TiO}_{2}\left(\mathrm{P} 25\right.$, Degussa) and $\mathrm{CeO}_{2}$ (Grace Davison)) or synthesised ( $\alpha$ $\mathrm{Fe}_{2} \mathrm{O}_{3}, \mathrm{Fe}_{3} \mathrm{O}_{4}$ and $\mathrm{ZrO}_{2}$ ) as described elsewhere [12,20]. Supported $\mathrm{Au}$ catalysts were prepared by deposition-precipitation using urea (Riedel-de Haën, 99\%) as basification agent. An aqueous solution of urea (100-fold excess) and $\mathrm{HAuCl}_{4}\left(3-7 \times 10^{-3} \mathrm{M}, 400 \mathrm{~cm}^{3}\right.$, Sigma Aldrich, 99\%) was added to the support (10-30 g). The suspension was stirred and heated (2 $\mathrm{K} \mathrm{min}^{-1}$ ) to $353 \mathrm{~K}$ where the $\mathrm{pH}$ progressively increased (to 6.5-8.0) as a result of urea decomposition:

$$
\mathrm{NH}_{2}-\mathrm{CO}-\mathrm{NH}_{2}+3 \mathrm{H}_{2} \mathrm{O} \stackrel{T=353 \mathrm{~K}}{\longrightarrow} 2 \mathrm{NH}_{4}^{+}+2 \mathrm{OH}^{-}+\mathrm{CO}_{2}
$$

The solid obtained was separated by filtration, washed with distilled water until $\mathrm{Cl}$ free (from $\mathrm{AgNO}_{3}$ test $)$ and dried $\left(2 \mathrm{~K} \mathrm{~min}^{-1}\right)$ in $45 \mathrm{~cm}^{3} \mathrm{~min}^{-1} \mathrm{He}$ at $373 \mathrm{~K}$ for $5 \mathrm{~h}$. The catalyst 
precursors were sieved (ATM fine test sieves) to mean particle diameter $=75 \mu \mathrm{m}$ and activated at $2 \mathrm{~K} \mathrm{~min}^{-1}$ to $423-673 \mathrm{~K}$ in $60 \mathrm{~cm}^{3} \mathrm{~min}^{-1} \mathrm{H}_{2}$. The catalysts were cooled to ambient temperature and passivated in $1 \% \mathrm{v} / \mathrm{v} \mathrm{O}_{2} / \mathrm{He}$ for off-line characterisation.

\subsection{Catalyst characterisation}

Gold content was measured by atomic absorption spectroscopy (Shimadzu AA-6650 spectrometer with an air-acetylene flame) from the diluted extract in aqua regia $(25 \% \mathrm{v} / \mathrm{v}$ $\left.\mathrm{HNO}_{3} / \mathrm{HCl}\right)$. The $\mathrm{pH}$ associated with the point of zero charge $\left(\mathrm{pH}_{\mathrm{pzc}}\right)$ of the support was determined using the potentiometric mass titration technique described in detail elsewhere [21]. Temperature programmed reduction (TPR), $\mathrm{H}_{2}$ chemisorption/temperature programmed desorption (TPD), $\mathrm{O}_{2}$ chemisorption and specific surface area (SSA) measurements were conducted on the CHEM-BET 3000 (Quantachrome) unit equipped with a thermal conductivity detector (TCD) for continuous monitoring of gas composition and the TPR $\mathrm{Win}^{\mathrm{TM}}$ software for data acquisition/manipulation. Samples were loaded into a U-shaped Pyrex quartz cell (3.76 $\mathrm{mm}$ i.d.) and heated in $17 \mathrm{~cm}^{3} \mathrm{~min}^{-1}$ (Brooks mass flow controlled) $5 \% \mathrm{v} / \mathrm{v} \mathrm{H}_{2} / \mathrm{N}_{2}$ at $2 \mathrm{~K} \mathrm{~min}^{-1}$ to $423-673 \mathrm{~K}$ for supported $\mathrm{Au}$ catalysts and to $1073-1273 \mathrm{~K}$ for the supports where the effluent gas passed through a liquid $\mathrm{N}_{2}$ trap. The activated samples were swept with $65 \mathrm{~cm}^{3} \mathrm{~min}^{-1} \mathrm{~N}_{2}$ for $1.5 \mathrm{~h}$, cooled to reaction temperature $(413 \mathrm{~K})$ and subjected to a $\mathrm{H}_{2}(\mathrm{BOC},>99.98 \%)$ pulse $(10 \mu \mathrm{l})$ titration procedure. Samples were cooled to ambient temperature, thoroughly flushed in $\mathrm{N}_{2}\left(65 \mathrm{~cm}^{3} \mathrm{~min}^{-1}\right)$ to remove weakly bound $\mathrm{H}_{2}$ and subjected to TPD (at $50 \mathrm{~K} \mathrm{~min}^{-1}$ ) to $873-1173 \mathrm{~K}$ with a final isothermal hold until the signal returned to baseline. Oxygen (BOC, 99.9\%) pulse $(50 \mu \mathrm{l})$ titration at $413 \mathrm{~K}$ post-TPR was employed to determine the extent of support reduction where any contribution from $\mathrm{Au}$ to total $\mathrm{O}_{2}$ adsorption is negligible [22]. SSA (reproducible to $\pm 8 \%$ ) was recorded in $30 \% \mathrm{v} / \mathrm{v}$ $\mathrm{N}_{2} / \mathrm{He}$ with undiluted $\mathrm{N}_{2}(\mathrm{BOC}, 99.9 \%)$ as internal standard. At least three cycles of $\mathrm{N}_{2}$ adsorption-desorption were employed using the standard single point BET method. Pore 
volume was measured using the Micromeritics Gemini VII 2390p system. Prior to analysis, samples were outgassed at $423 \mathrm{~K}$ for $1 \mathrm{~h}$ in $\mathrm{N}_{2}$. Total pore volume was obtained at a relative $\mathrm{N}_{2}$ pressure $\left(P / P_{0}\right)=0.95$. X-ray diffractograms $(\mathrm{XRD})$ were recorded on a Bruker/Siemens D500 incident X-ray diffractometer using $\mathrm{Cu} \mathrm{K \alpha}$ radiation. Samples were scanned at $0.02^{\circ}$ step $^{-1}$ over the range $20^{\circ} \leq 2 \theta \leq 80^{\circ}$ and the diffractograms identified against the JCPDSICDD reference standards, i.e. $\mathrm{Au}(04-0784), \gamma-\mathrm{Al}_{2} \mathrm{O}_{3}(10-0425)$, anatase- $\mathrm{TiO}_{2}\left(\mathrm{~A}-\mathrm{TiO}_{2}, 21-\right.$ 1272), rutile- $\mathrm{TiO}_{2}\left(\mathrm{R}-\mathrm{TiO}_{2}, 21-1276\right)$, monoclinic- $\mathrm{ZrO}_{2}\left(\mathrm{M}-\mathrm{ZrO}_{2}, 37-1784\right)$, tetragonal- $\mathrm{ZrO}_{2}$ (T- $\left.\mathrm{ZrO}_{2}, 50-1089\right), \mathrm{CeO}_{2}$ (43-1002), $\alpha-\mathrm{Fe}_{2} \mathrm{O}_{3}$ (hematite, 33-0664) and $\mathrm{Fe}_{3} \mathrm{O}_{4}$ (magnetite, 190629). X-ray photoelectron spectroscopic (XPS) analysis was performed on a VG ESCA spectrometer equipped with monochromatised $\mathrm{Al} \mathrm{K \alpha}$ radiation $(1486 \mathrm{eV})$. The sample was adhered to conducting carbon tape, mounted in the sample holder and subjected to ultra-high vacuum conditions ( $<10^{-8}$ Torr). Full range surveys ( $\mathrm{Au} 4 f_{5 / 2}$ and $4 f_{7 / 2}$ spectra) were collected where the binding energies (BE) were calibrated with respect to the $\mathrm{C} 1 \mathrm{~s}$ peak $(284.5 \mathrm{eV})$. The $\mathrm{Au} 4 f$ spectra were fitted with abstraction of the Shirley background using the GaussianLorentzian function in XPSPEAK 41. Gold particle morphology (size and shape) was examined by transmission (TEM, JEOL JEM 2011) and scanning transmission (STEM, JEOL 2200FS field emission gun-equipped unit) electron microscopy, employing Gatan Digital Micrograph 1.82 for data acquisition/manipulation. Samples for analysis were dispersed in acetone and deposited on a holey carbon/Cu grid (300 Mesh). The surface area weighted mean Au size $(d)$ was based on a count of at least 300 particles according to

$$
d=\frac{\sum_{i} n_{i} d_{i}^{3}}{\sum_{i} n_{i} d_{i}^{2}}
$$

where $n_{i}$ is the number of particles of diameter $d_{i}$. 


\subsection{Catalytic procedure}

Catalyst testing was carried out at atmospheric pressure, in situ after activation, in a continuous flow fixed bed tubular reactor $($ i.d. $=15 \mathrm{~mm}$ ) at $413-573 \mathrm{~K}$ under conditions of negligible heat/mass transport limitations. A layer of borosilicate glass beads served as preheating zone, ensuring the organic reactant was vaporised and reached reaction temperature before contacting the catalyst $(10-40 \mathrm{mg})$. Isothermal conditions $( \pm 1 \mathrm{~K})$ were maintained by diluting the catalyst bed with ground glass $(75 \mu \mathrm{m})$. Reaction temperature was continuously monitored by a thermocouple inserted in a thermowell within the catalyst bed. Reactants (benzaldehyde (Fluka, $\geq 98 \%$ ), nitrobenzene (Riedel-de Haën, $\geq 99 \%$ ) or benzyl alcohol (Riedel-de Haën, $\geq 99 \%$ )) were delivered as an ethanolic (Sigma Aldrich, $\geq 99 \%$ ) solution to the reactor via a glass/teflon air-tight syringe and teflon line using a microprocessor controlled infusion pump (Model $100 \mathrm{kd}$ Scientific) at a fixed calibrated flow rate. Reactions were conducted in a co-current flow of reactant with $\mathrm{H}_{2}\left(\mathrm{BOC},>99.98 \%, 60 \mathrm{~cm}^{3}\right.$ $\left.\min ^{-1}\right)$ at $G H S V=2 \times 10^{4} \mathrm{~h}^{-1}$. The molar Au to inlet organic molar feed rate $(n / F)$ spanned the range $1.2 \times 10^{-3}-3.7 \times 10^{-3} \mathrm{~h}$. In blank tests, passage of each reactant in a stream of $\mathrm{H}_{2}$ through the empty reactor or over the support did not result in any detectable conversion. The reactor effluent was collected in a liquid nitrogen trap for subsequent analysis using a Perkin-Elmer Auto System XL gas chromatograph equipped with a programmed split/splitless injector and a flame ionization detector (FID), employing a DB-1 $(50 \mathrm{~m} \times 0.33 \mathrm{~mm}$ i.d., $0.20 \mu \mathrm{m}$ film thickness) capillary column (J\&W Scientific). Data acquisition and manipulation were performed using the TurboChrom Workstation Version 6.3.2 (for Windows) chromatography data system. Reactant conversion $(X)$ is defined by

$$
X(\%)=\frac{[\text { reactant }]_{\text {in }}-[\text { reactant }]_{\text {out }}}{[\text { reactant }]_{\text {in }}} \times 100
$$

and selectivity $(S)$ to product $(\mathrm{j})$ is given by 


$$
S_{\mathrm{j}}(\%)=\frac{[\text { product }]_{\mathrm{j}, \text { out }}}{[\text { reactant }]_{\mathrm{in}}-[\text { reactant }]_{\text {out }}} \times 100
$$

where subscripts "in" and "out" refer to inlet and outlet gas streams. Catalytic activity is also quantified in terms of initial conversion obtained from time on-stream measurements and turnover frequency (TOF, rate per active site) calculated using Au dispersion $(D)$ obtained from STEM analysis [23] according to:

$$
\text { TOF }\left(\mathrm{h}^{-1}\right)=\frac{R}{D}
$$

where $R$ represents reactant consumption rate $\left(\right.$ mol $_{\text {reactant }}$ mol $\left._{\text {metal }}{ }^{-1} \mathrm{~h}^{-1}\right)$. Repeated reactions with different samples from the same batch of catalyst delivered raw data reproducibility and mass balances within $\pm 5 \%$.

\section{Results and discussion}

\subsection{Catalyst characterisation}

\subsubsection{Structural characteristics and temperature programmed reduction (TPR)}

Catalyst physico-chemical characteristics are presented in Table 1. SSA range from 11 $\mathrm{m}^{2} \mathrm{~g}^{-1}\left(\mathrm{Au} / \mathrm{Fe}_{3} \mathrm{O}_{4}\right)$ to $166 \mathrm{~m}^{2} \mathrm{~g}^{-1}\left(\mathrm{Au} / \gamma-\mathrm{Al}_{2} \mathrm{O}_{3}\right)$ with a corresponding increase in pore volume $\left(0.02-0.36 \mathrm{~cm}^{3} \mathrm{~g}^{-1}\right)$. Values obtained for each catalyst are in good agreement with those reported in the literature [24-27]. The TPR profiles of the supported Au catalyst precursors and corresponding supports are presented in Fig. 1. TPR of $\mathrm{Au} / \gamma-\mathrm{Al}_{2} \mathrm{O}_{3}$ (AI) and $\mathrm{Au} / \mathrm{ZrO}_{2}$ (CI) generated positive signals with associated temperature maxima $\left(T_{\max }\right)$ at 451 and $476 \mathrm{~K}$,

respectively where $\mathrm{H}_{2}$ consumption matched the requirement for $\mathrm{Au}^{3+}$ reduction to $\mathrm{Au}^{0}$ (Table 1). The profiles generated for the $\gamma-\mathrm{Al}_{2} \mathrm{O}_{3}$ (AII) and $\mathrm{ZrO}_{2}$ (CII) supports were featureless with no evidence of $\mathrm{H}_{2}$ uptake or release, as noted elsewhere [25]. Activation of $\mathrm{Au} / \mathrm{TiO}_{2}(\mathbf{B I})$ and $\mathrm{Au} / \mathrm{CeO}_{2}$ (DI) presented $\mathrm{H}_{2}$ consumption peaks at lower temperatures ( $T_{\max }$ $=364$ and $420 \mathrm{~K}$ ) suggesting weaker metal-support interactions. This is consistent with the work of Delannoy et al. [28] who examined the effect of support redox character on $\mathrm{Au}$ 
reducibility and reported more facile reduction on $\mathrm{TiO}_{2}$ and $\mathrm{CeO}_{2}$ relative to $\mathrm{Al}_{2} \mathrm{O}_{3}$. Hydrogen consumed during TPR of $\mathrm{Au} / \mathrm{TiO}_{2}$ exceeded that required for $\mathrm{Au}^{3+} \rightarrow \mathrm{Au}^{0}$ (Table 1) and can be attributed to a combined $\mathrm{Au}$ reduction with $\mathrm{Ti}^{4+}$ conversion to $\mathrm{Ti}^{3+}$ at the metal/support interface [29]. The bare $\mathrm{TiO}_{2}$ support did not exhibit a detectable TPR response (BII). In contrast, thermal treatment of $\mathrm{CeO}_{2}$ generated two broad signals at $742 \mathrm{~K}$ and 1148 $\mathrm{K}$ (DII) that can be ascribed to surface (523-848 K [30]) and bulk (>1073 K [30]) reduction. Hydrogen consumed during the activation of $\mathrm{Au} / \mathrm{CeO}_{2}$ exceeded $\mathrm{Au}$ precursor reduction (Table 1) but was significantly lower than the amount needed for full reduction of the $\mathrm{CeO}_{2}$ carrier $\left(3300 \mu \mathrm{mol} \mathrm{g} \mathrm{g}^{-1}\right)$. This suggests partial support reduction where the incorporation of $\mathrm{Au}$ on $\mathrm{CeO}_{2}$ lowered the requisite temperature [31]. TPR of $\mathrm{Au} / \alpha-\mathrm{Fe}_{2} \mathrm{O}_{3}$ (EI) resulted in excess $\mathrm{H}_{2}$ consumption at $T_{\max }=389 \mathrm{~K}$ whereas TPR of $\alpha-\mathrm{Fe}_{2} \mathrm{O}_{3}$ (EII) generated a signal at $709 \mathrm{~K}$ with a broader consumption at $T>800 \mathrm{~K}$ suggesting a two-stage reduction of hematite, i.e. $\alpha$ $\mathrm{Fe}_{2} \mathrm{O}_{3} \rightarrow \mathrm{Fe}_{3} \mathrm{O}_{4} \rightarrow \mathrm{FeO}$. The TPR response for $\mathrm{Au} / \mathrm{Fe}_{3} \mathrm{O}_{4}$ (FI) also reveals a down shift in $T_{\max }$ relative to the support (FII). The excess $\mathrm{H}_{2}$ consumed (Table 1) fell below that for conversion of $\mathrm{Fe}_{3} \mathrm{O}_{4}$ to $\mathrm{FeO}\left(4250 \mu \mathrm{mol} \mathrm{g}{ }^{-1}\right)$ again indicative of partial support reduction. Our results demonstrate a more facile reduction of ceria and iron oxide supports due to the presence of $\mathrm{Au}$. Jacobs et al. [32] have established partial $\mathrm{CeO}_{2}$ reduction by spillover hydrogen following dissociative adsorption on supported Au. Furthermore, Scirè and coworkers [33] proposed that $\mathrm{Au}$ can weaken the $\mathrm{Fe}-\mathrm{O}$ bond in iron oxide substrates resulting in greater lattice oxygen mobility and enhanced reducibility.

\subsubsection{Hydrogen temperature programmed desorption (TPD) and $\mathrm{O}_{2}$ chemisorption}

Application of TPD to measure surface hydrogen release can allow differentiation between chemisorbed and spillover species which both serve as reactive hydrogen in hydrogenation [34]. The TPD profiles generated for all the catalysts are shown in Fig. 2 . The literature suggests a lower temperature requirement for $\mathrm{H}_{2}$ desorption from metal sites $(<473$ 
K) compared with release of spillover from the support ( $>503 \mathrm{~K})$ [35]. A predominant $\mathrm{H}_{2}$ desorption at $T_{\max } \geq 575 \mathrm{~K}$ was observed in this work suggesting that the main contribution is due to spillover. Hydrogen spillover is influenced by the concentration of initiating and acceptor sites, catalyst activation and metal nanoparticle size (i.e. degree of contact between participating phases and metal-support interaction(s)) [35]. As a general observation, $\mathrm{H}_{2}$ release from $\mathrm{Au}$ supported on non-reducible $\left(\mathrm{Al}_{2} \mathrm{O}_{3}, \mathrm{ZrO}_{2}\right)$ supports $\left(28-51 \mathrm{mmol} \mathrm{gAu}^{-1}\right)$ was significantly greater than that recorded for $\mathrm{Au}$ on reducible carriers $\left(\leq 9 \mathrm{mmol} \mathrm{gAu}^{-1}\right)$. There is compelling evidence in the literature for hydrogen spillover onto $\mathrm{Al}_{2} \mathrm{O}_{3}[34,35]$ and $\mathrm{ZrO}_{2}$ [36,37] from supported metals ( $\mathrm{Pd}, \mathrm{Ni}, \mathrm{Cu}$ and $\mathrm{Ru})$. The greater $\mathrm{H}_{2}$ desorption from $\mathrm{Au} / \gamma-$ $\mathrm{Al}_{2} \mathrm{O}_{3}$ relative to $\mathrm{Au} / \mathrm{ZrO}_{2}$ can be attributed (at least in part) to the higher SSA of $\mathrm{Al}_{2} \mathrm{O}_{3}$ which can accommodate more spillover. Consumption of spillover hydrogen in the partial reduction of (reducible) titania, ceria and iron oxide can account for the observed lower levels of $\mathrm{H}_{2}$ TPD [34]. We employed $\mathrm{O}_{2}$ chemisorption post-TPR as a measure of support reduction [22]. Gold on $\mathrm{CeO}_{2}, \alpha-\mathrm{Fe}_{2} \mathrm{O}_{3}$ and $\mathrm{Fe}_{3} \mathrm{O}_{4}$ exhibited greater $\mathrm{O}_{2}$ uptake (Table 1) than that measured for $\mathrm{Au} / \mathrm{TiO} 2, \mathrm{Au} / \gamma-\mathrm{Al}_{2} \mathrm{O}_{3}$ and $\mathrm{Au} / \mathrm{ZrO}_{2}$. The difference in $\mathrm{O}_{2}$ adsorption can be correlated with support redox character [38], where the former group of oxides are characterised by higher redox potentials $\left(E_{\text {redox }}\right)$ (Table 1). Increasing $\mathrm{O}_{2}$ chemisorption coincided with greater excess $\mathrm{H}_{2}$ consumption during TPR due to support reduction with the formation of oxygen vacancies. Oxygen deficient sites can be generated by loss of lattice oxygen from reducible metal oxides during thermal treatment in $\mathrm{H}_{2}$ or $\mathrm{CO}$ [39]. Boccuzzi et al. [40,41] demonstrated by FTIR spectroscopy the formation of oxygen vacancies following reduction in $\mathrm{H}_{2}$ of $\mathrm{Fe}_{2} \mathrm{O}_{3}$, $\mathrm{TiO}_{2}$ and $\mathrm{CeO}_{2}$ to $523 \mathrm{~K}$. Moreover, formation of $\mathrm{Ce}^{3+}$ defects/surface vacancies in $\mathrm{Au} / \mathrm{CeO}_{2}-$ $\mathrm{Fe}_{2} \mathrm{O}_{3}$ has been linked to the action of spillover hydrogen [42]. 


\subsection{3. $X$-ray diffraction (XRD) and electron microscopy analysis}

Structural analysis by XRD generated the diffractograms presented in Fig. 3. There was no clearly discernible peak for $\mathrm{Au}\left(\right.$ at $2 \theta=38.1^{\circ}$ ) which may be due to masking by stronger signals due to the support or the formation of Au particles at the nano-scale and below detection limit $(<5 \mathrm{~nm})$ [43]. The XRD pattern of $\mathrm{Au} / \gamma-\mathrm{Al}_{2} \mathrm{O}_{3}$ is characterised by peaks at $2 \theta$ $=37.6^{\circ}, 39.5^{\circ}, 45.9^{\circ}$ and $67.0^{\circ}$ due to cubic $\gamma-\mathrm{Al}_{2} \mathrm{O}_{3} . \mathrm{XRD}$ analysis of $\mathrm{Au} / \mathrm{TiO}_{2}$ revealed a mixture of tetragonal anatase $\left(2 \theta=25.3^{\circ}, 37.8^{\circ}, 48.1^{\circ}\right.$ and $\left.62.8^{\circ}\right)$ and tetragonal rutile $(2 \theta=$ $27.4^{\circ}, 36.1^{\circ}, 41.2^{\circ}, 54.3^{\circ}, 56.6^{\circ}, 69.0^{\circ}$ and $\left.69.8^{\circ}\right)$ phases with an anatase:rutile ratio $(5: 1)$ that matches the reported Degussa P25 composition [44]. $\mathrm{Au} / \mathrm{ZrO}_{2}$ showed mixed monoclinic (20 $=28.2^{\circ}, 31.5^{\circ}, 34.2^{\circ}, 34.4^{\circ}, 35.3^{\circ}, 40.8^{\circ}, 49.3^{\circ}, 50.2^{\circ}, 50.6^{\circ}$ and $\left.55.6^{\circ}\right)$ and tetragonal $(2 \theta=$ $30.3^{\circ}, 35.3^{\circ}, 50.4^{\circ}, 50.7^{\circ}, 59.6^{\circ}$ and $60.2^{\circ}$ ) phases with monoclinic/tetragonal $\sim 2$. Zirconia phase composition is sensitive to synthesis route and calcination temperature with ratios in the range 1.2-3.2 reported for comparable $\mathrm{ZrO}_{2}$ preparation and pre-treatment [25]. The XRD patterns of $\mathrm{Au}$ on $\mathrm{CeO}_{2}, \alpha-\mathrm{Fe}_{2} \mathrm{O}_{3}$ and $\mathrm{Fe}_{3} \mathrm{O}_{4}$ (Fig. 3(D-F)) match those of the supports and we can discount bulk support reduction, i.e. $\mathrm{CeO}_{2} \rightarrow \mathrm{Ce}_{2} \mathrm{O}_{3}, \mathrm{Fe}_{2} \mathrm{O}_{3} \rightarrow \mathrm{Fe}_{3} \mathrm{O}_{4}$ and $/$ or $\mathrm{Fe}_{3} \mathrm{O}_{4} \rightarrow$ $\mathrm{FeO}$.

Gold particle morphology was evaluated by TEM/STEM and the representative images in Fig. 4 reveal quasi-spherical particles at the nano-scale. Surface area weighted mean Au size was obtained from the size distribution histograms and are recorded in Table 1. Gold on $\gamma-\mathrm{Al}_{2} \mathrm{O}_{3}$ (A) exhibited metal particles in the $1-8 \mathrm{~nm}$ range with a mean of $4.3 \mathrm{~nm}$. Appreciably larger $\mathrm{Au}$ particles $(2-12 \mathrm{~nm}$, mean $=7.0 \mathrm{~nm})$ are observed on $\mathrm{ZrO}_{2}(\mathbf{C})$, consistent with the report of Mohr et al. [45] for $\mathrm{Au} / \mathrm{ZrO}_{2}$ preparation by deposition-precipitation. Reducible $\mathrm{CeO}_{2}$ (D) and $\alpha-\mathrm{Fe}_{2} \mathrm{O}_{3}$ (E) supports show narrower Au size distribution (1-5 nm) and smaller mean values $(2.0-2.6 \mathrm{~nm})$ than $\mathrm{Au} / \mathrm{TiO}_{2}(\mathbf{B}), 1-9 \mathrm{~nm}$, mean $\left.=4.5 \mathrm{~nm}\right)$. Support oxygen vacancies stabilise transition metal nanoparticles and inhibit sintering [46], which may result 
in the formation of smaller $\mathrm{Au}$ particles on $\alpha-\mathrm{Fe}_{2} \mathrm{O}_{3}$ and $\mathrm{CeO}_{2}$ that bear a greater number of vacancies than $\mathrm{Au} / \mathrm{TiO}_{2}$ (Table 1). It should be noted that a wider $\mathrm{Au}$ size range and mean $(=7.6 \mathrm{~nm})$ characterised $\mathrm{Au} / \mathrm{Fe}_{3} \mathrm{O}_{4}$. Support charge density, reflected in the $\mathrm{pH}$ point of zero charge $\left(\mathrm{pH}_{\mathrm{pzc}}\right)$, determines precursor-support interaction in synthesis by depositionprecipitation and can govern ultimate $\mathrm{Au}$ size post-TPR. Where solution $\mathrm{pH}<\mathrm{pH}_{\mathrm{pzc}}$, the support bears a positive charge favouring interaction with anionic Au species. Conversely, where solution $\mathrm{pH}>\mathrm{pH}_{\mathrm{pzc}}$ the $\mathrm{Au}$ precursor and support experience repulsive effects due to the negative surface charge resulting in weaker Au-support interaction leading to $\mathrm{Au}$ agglomeration during activation [47]. Solution $\mathrm{pH}$ controls $\mathrm{AuCl}_{4}^{-}$hydrolysis rate via substitution of $\mathrm{Cl}^{-}$by $\mathrm{OH}^{-}$where $\mathrm{Au}(\mathrm{OH})_{4}^{-}$predominates at the final $\mathrm{pH}$ (6.5-8.0, see experimental section 2.1.) [48]. Support $\mathrm{pH}_{\mathrm{pzc}}$ are given in Table 1 where the lower value for $\mathrm{Fe}_{3} \mathrm{O}_{4}$ (5.8) does not favour interaction with (anionic) Au precursor species and can account for larger Au size.

\subsubsection{X-ray photoelectron spectroscopy (XPS) analysis}

XPS measurements were conducted to probe support effects in modifying Au electronic character. XPS profiles over the Au $4 f$ binding energy (BE) region are given in Fig. 5. The Au $4 f_{7 / 2} \mathrm{BE}$ for $\mathrm{Au} / \gamma-\mathrm{Al}_{2} \mathrm{O}_{3}(83.3 \mathrm{eV})$ and $\mathrm{Au} / \mathrm{TiO}_{2}(83.5 \mathrm{eV})$ are close to values reported in the literature $\left(\mathrm{Au} / \mathrm{Al}_{2} \mathrm{O}_{3}(83.1 \mathrm{eV})[49]\right.$ and $\left.\mathrm{Au} / \mathrm{TiO}_{2}(83.3 \mathrm{eV})[50]\right)$ and fall below the reference metallic Au (83.7-84.0 eV) [51], indicative of electron donation from the support [52]. Gold on $\mathrm{CeO}_{2}$ (Table 1) exhibits an $\mathrm{Au} 4 f_{7 / 2} \mathrm{BE}$ consistent with that published for $\mathrm{Au} / \mathrm{CeO}_{2}(84.5$ eV) [53] but lower than $\mathrm{Au}^{+}(85.8-86.0 \mathrm{eV})$ [51]. A partial positive charge $\left(\mathrm{Au}^{\delta+}\right)$ has been proposed for $\mathrm{Au} / \mathrm{CeO}_{2}$ resulting from electron transfer from $\mathrm{Au}$ [54]. The data presented in Fig. 6 show a dependence of $\mathrm{Au} 4 f_{7 / 2} \mathrm{BE}$ on support redox potential where electron transfer from $\mathrm{Au}$ is facilitated by carriers with higher potential. Gold electronic structure is also dependent on $\mathrm{Au}$ cluster size where any shift in BE is more pronounced with decreasing 
coordination number [55]. The formation of smaller particles on $\mathrm{Au} / \mathrm{CeO}_{2}$ can also contribute to an upshift of BE.

\subsection{Catalyst activity/selectivity}

Benzyl alcohol was the sole product detected in the hydrogenation of benzaldehyde at $413 \mathrm{~K}$. In contrast, gas phase $(383-413 \mathrm{~K})$ benzaldehyde conversion over $\left(\mathrm{SiO}_{2}, \mathrm{Al}_{2} \mathrm{O}_{3}, \mathrm{TiO}_{2}\right.$, $\mathrm{CeO}_{2}$ and $\mathrm{ZrO}_{2}$ ) supported $\mathrm{Cu}$ and $\mathrm{Ni}$ resulted in $-\mathrm{CH}=\mathrm{O}$ hydrogenolysis (to toluene) and/or C-C scission (to benzene) [56,57]. The relationship between benzaldehyde turnover frequency (TOF at $413 \mathrm{~K}$ ) and Au particle size $(d)$ is shown in Fig. 7(I). An increase in TOF is evident with decreasing $\mathrm{Au}$ particle size over the 8-4 $\mathrm{nm}$ range which can be linked to greater $\mathrm{H}_{2}$ uptake under reaction conditions (Table 1). The highest specific rate was recorded for $\mathrm{Au} / \gamma-\mathrm{Al}_{2} \mathrm{O}_{3}$ with no detectable activity for catalysts bearing the smallest $\mathrm{Au}$ sizes $(\mathrm{Au} / \alpha-$ $\mathrm{Fe}_{2} \mathrm{O}_{3}$ and $\mathrm{Au} / \mathrm{CeO}_{2}$ ). It has been established that $\mathrm{Au}$ exhibits metal to insulator transition for particles $\leq 3 \mathrm{~nm}[58]$ and decreasing hydrogenation activity for smaller Au particles $(5 \rightarrow 1$ $\mathrm{nm})$ has been ascribed to a critical loss of metallic character [59]. Although there is insufficient published data to arrive at any reliable trends regarding Au size effects in $-\mathrm{CH}=\mathrm{O}$ hydrogenation, we can note the reported decrease in acrolein $\mathrm{TOF}$ over $\mathrm{Au} / \mathrm{ZrO} \mathrm{r}_{2}$ for $\mathrm{Au}$ particles $>4 \mathrm{~nm}$ [45] and increase with increasing $\mathrm{Au}$ size $(1-5 \mathrm{~nm})$ over $\mathrm{Au} / \mathrm{ZrO} 2$ and $\mathrm{Au} / \mathrm{TiO}_{2}$ [59]. In contrast to the benzaldehyde reaction, each catalyst was active in nitrobenzene hydrogenation (Fig. 7(II)) with a TOF maximum for $\mathrm{Au} / \gamma-\mathrm{Al}_{2} \mathrm{O}_{3}$. The greater reactivity of the nitro-reactant agrees with results (for $\mathrm{Pt} / \mathrm{Al}_{2} \mathrm{O}_{3}$ ) reported by Arai et al. [60] where a six-fold higher rate was recorded for nitrobenzene relative to benzaldehyde hydrogenation. This was linked to reaction thermodynamics where nitrobenzene to aniline $\left(\Delta \mathrm{G}_{413 \mathrm{~K}}=-436 \pm 1 \mathrm{~kJ} \mathrm{~mol}^{-1}\right)$ is more favourable than benzaldehyde hydrogenation to benzyl $\operatorname{alcohol}\left(\Delta \mathrm{G}_{413 \mathrm{~K}}=-24 \pm 2 \mathrm{~kJ} \mathrm{~mol}^{-1}\right)$. 
With respect to support reducibility, TOF was higher at lower redox potential as shown in Fig. 8. $\mathrm{Au} / \mathrm{ZrO}_{2}$ deviates somewhat from the general trend, which we tentatively attribute to the occurrence of larger Au particles (Fig. 4(C)) that show low activity in hydrogenation. Lower TOF at higher redox potential suggests that oxygen vacancies on reducible supports do not favour $-\mathrm{CH}=\mathrm{O}$ or $-\mathrm{NO}_{2}$ activation for reaction. It is known that these vacancies can strongly bind adsorbed oxygenated species [61]. Gold on non-reducible $\gamma-\mathrm{Al}_{2} \mathrm{O}_{3}$ with the formation of $\mathrm{Au}^{\delta-}$ (from XPS analysis) delivered the highest TOF. This agrees with published studies $[16,62]$ which have shown that $-\mathrm{CH}=\mathrm{O}$ activation and alcohol formation is facilitated on negatively charged Au via interaction with the electrophilic carbon. Given the negligible benzaldehyde hydrogenation activity over catalysts with smaller $(<4 \mathrm{~nm})$ and larger $(>7 \mathrm{~nm})$ $\mathrm{Au}$ particles at $413 \mathrm{~K}$, we evaluated the effect of reaction temperature on rate and selectivity for $\mathrm{Au} / \mathrm{CeO}_{2}$ and $\mathrm{Au} / \mathrm{Fe}_{3} \mathrm{O}_{4}$ which can be compared with $\mathrm{Au} / \gamma-\mathrm{Al}_{2} \mathrm{O}_{3}$ in Table 2 . In each case an increase in TOF was observed at higher temperature. A switch was observed from exclusive $-\mathrm{CH}=\mathrm{O}$ hydrogenation (to benzyl alcohol) at $413 \mathrm{~K}$ to hydrogenolysis (to toluene) at $473 \mathrm{~K}$ with a predominant aryl-carbonyl hydrogenolytic scission (to benzene) at $573 \mathrm{~K}$ over $\mathrm{Au} / \gamma-\mathrm{Al}_{2} \mathrm{O}_{3}$. A higher temperature (to $498 \mathrm{~K}$ ) has been shown to promote benzaldehyde conversion to toluene and benzene over $\mathrm{Cu} / \mathrm{Al}_{2} \mathrm{O}_{3}$ [56] and $\mathrm{Ni} / \mathrm{SiO}_{2}$ [63]. Benzaldehyde hydrogenation to benzyl alcohol was not observed over $\mathrm{Au} / \mathrm{Fe}_{3} \mathrm{O}_{4}$ and $\mathrm{Au} / \mathrm{CeO}_{2}$ at any reaction temperature (Table 2). Increased temperature generated toluene as principal product with higher selectivity to benzene at $573 \mathrm{~K}$ (Table 2). Gold on redox supports exhibited a dominant hydrogenolytic character. Reaction of benzyl alcohol as feedstock (at $573 \mathrm{~K}$ ) over $\mathrm{Au} / \mathrm{Fe}_{3} \mathrm{O}_{4}$ generated toluene as principal product and benzaldehyde (with no detectable benzene) at a similar TOF to that recorded for the benzaldehyde reaction (Table 3). This points to production of toluene from benzaldehyde via consecutive conversion of benzyl alcohol whereas benzene is generated from aldehyde hydrogenolysis. Benzaldehyde was the 
principal product in reaction over $\mathrm{Au} / \mathrm{CeO}_{2}$, which can be attributed to oxidative dehydrogenation [64]. This step involves the catalytic action of surface or lattice oxygens associated with the support and the high aldehyde selectivity exhibited by $\mathrm{Au} / \mathrm{CeO}_{2}$ (Table 3) must be due to greater oxygen mobility relative to $\mathrm{Fe}_{3} \mathrm{O}_{4}$ as inferred from $\mathrm{O}_{2}$ chemisorption (Table 1).

Surface oxygen vacancies have been proposed as active sites in a range of applications from automobile exhaust treatment [65], water-gas shift [66] to steam reforming of oxygenates [67]. There is ample evidence that these vacancies can participate in a Mars and van Krevelen (MvK) mechanism with catalyst surface reduction (oxygen depletion) and reoxidation (oxygen generation) [68]. We propose the involvement of oxygen vacancies in MvK catalytic hydrogenation, as illustrated in Fig. 9. The vacancies, created through $\mathrm{H}_{2}$ chemisorbed on $\mathrm{Au}$ that spills onto the support (step A, Fig. 9(I)) with $\mathrm{H}_{2} \mathrm{O}$ release, act as strong anchoring sites for the carbonyl group (steps B and C) [69], inhibiting reactivity. The stabilised carbonyl function can be activated at elevated temperature (473 K) with benzyl alcohol formation and subsequent hydrogenolysis (step D) or direct hydrogen scission of the $-\mathrm{CH}=\mathrm{O}$ bond (step $\mathrm{E}$ ) to benzene. Higher temperature facilitates hydrogen cleavage to give benzene (step F). In contrast, adsorption on non-reducible surfaces (e.g. $\mathrm{Al}_{2} \mathrm{O}_{3}$ ) via the carbonyl function (step A, Fig. 10) results in hydrogenation to the alcohol at low reaction temperature $(413 \mathrm{~K})$. DFT calculations have shown that a perpendicular adsorption mode is the most stable configuration with $-\mathrm{CH}=\mathrm{O}$ bonded to the metal oxide surface via the oxygen lone electron pair that acts as a Lewis base [70]. FTIR analysis has demonstrated that surface Lewis acid sites on $\mathrm{Al}_{2} \mathrm{O}_{3}$ promote $-\mathrm{CH}=\mathrm{O}$ activation in the hydrogenation of nitrobenzaldehyde [71]. Activation and scission of $-\mathrm{CH}_{2}-\mathrm{OH}$ (steps $\mathrm{B}$ and $\mathrm{C}$, Fig. 10), $-\mathrm{CH}=\mathrm{O}$ (step D) and the aryl-carbonyl bond (steps $\mathrm{E}$ and $\mathrm{F}$ ) is promoted at elevated temperature (473-573 K) with the formation of toluene and benzene. In the conversion of 
nitrobenzene (Fig. 9(II)) nitro group interaction with oxygen vacancies (steps A and B) has been proposed [72]. Attachment to surface vacancies can also stabilise the nitro group with lower resultant reaction rates but the greater reactivity of the $-\mathrm{NO}_{2}$ function (relative to $-\mathrm{CH}=\mathrm{O}$ ) resulted in measurable activity for each catalyst at $413 \mathrm{~K}$. Interaction of $-\mathrm{NO}_{2}$ with an oxygen vacancy and $\mathrm{N}-\mathrm{O}$ bond dissociation generates nitrosobenzene (step $\mathrm{C}$ ) with subsequent reduction to a phenylhydroxylamine intermediate (step D) and aniline formation and release (step E) [68]. Dissociative interaction of $\mathrm{H}_{2} \mathrm{O}$ with oxygen vacancies serves to reoxidise the support.

\section{Conclusions}

We have demonstrated that oxide support reducibility and Au size (mean $=2-8 \mathrm{~nm}$ ) governs the catalytic performance of $\mathrm{Au}$ in the reduction of $-\mathrm{CH}=\mathrm{O}$ (benzaldehyde) and $-\mathrm{NO}_{2}$ (nitrobenzene). TPR coupled with oxygen chemisorption has established partial support $\left(\mathrm{TiO}_{2}, \mathrm{CeO}_{2}, \alpha-\mathrm{Fe}_{2} \mathrm{O}_{3}\right.$ and $\left.\mathrm{Fe}_{3} \mathrm{O}_{4}\right)$ reduction due to the action of spillover hydrogen generated by $\mathrm{H}_{2}$ dissociation on $\mathrm{Au}$. XPS analysis provided evidence of electron transfer between $\mathrm{Au}$ and the oxide carriers. Increasing reaction rates were observed with decreasing Au size (from 8 to $4 \mathrm{~nm})$ with measurably lower rates over $\mathrm{Au}<3 \mathrm{~nm}$. Gold on reducible supports $\left(\mathrm{CeO}_{2}, \alpha-\right.$ $\mathrm{Fe}_{2} \mathrm{O}_{3}$ and $\mathrm{Fe}_{3} \mathrm{O}_{4}$ where $E_{\text {redox }}>0$ ) exhibited lower benzaldehyde and nitrobenzene TOF relative to $\mathrm{Au} / \gamma-\mathrm{Al}_{2} \mathrm{O}_{3}, \mathrm{Au} / \mathrm{TiO}_{2}$ and $\mathrm{Au} / \mathrm{ZrO}_{2}\left(E_{\text {redox }}<0\right)$, which we attribute to inhibition due to the action of surface oxygen vacancies. There was no measurable benzaldehyde hydrogenation activity over $\mathrm{Au} / \mathrm{CeO}_{2}, \mathrm{Au} / \alpha-\mathrm{Fe}_{2} \mathrm{O}_{3}$ and $\mathrm{Au} / \mathrm{Fe}_{3} \mathrm{O}_{4}$ at $413 \mathrm{~K}$. Reaction at higher temperatures generated toluene as principal product with secondary benzene formation and no detectable alcohol production. In contrast, reaction over $\mathrm{Au} / \gamma-\mathrm{Al}_{2} \mathrm{O}_{3}$ resulted in exclusive benzyl alcohol formation at $413 \mathrm{~K}$ with a progressive shift to hydrogenolysis (to toluene and benzene) at higher temperatures. 


\section{Acknowledgements}

The authors are grateful to Dr. N. Perret for her involvement in this work. EPSRC support for free access to the TEM facility at the University of St. Andrews and financial support to M. Li and X. Wang through the Overseas Research Students Award Scheme (ORSAS) are also acknowledged.

\section{References}

[1] M. Turáková, T. Salmi, K. Eränen, J. Wärnå, D. Y. Murzin, M. Králik, Appl. Catal. A: Gen. 499 (2015) 66-76.

[2] J. Scognamiglio, L. Jones, D. Vitale, C. S. Letizia, A. M. Api, Food Chem. Toxicol. 50, Supplement 2 (2012) S140-S160.

[3] V. van Brunt, J. S. Kanel, in: S. Kulprathipanja (Ed.), Reactive Separation Processes, Taylor \& Francis, London, 2002, pp. 51-92.

[4] R. J. Giraud, P. A. Williams, A. Sehgal, E. Ponnusamy, A. K. Phillips, J. B. Manley, ACS Sust. Chem. Eng. 2 (2014) 2237-2242.

[5] T. Mitsudome, K. Kaneda, Green Chem. 15 (2013) 2636-2654.

[6] E. Bus, J. T. Miller, J. A. van Bokhoven, J. Phys. Chem. B 109 (2005) 14581-14587.

[7] L. McEwan, M. Julius, S. Roberts, J. C. Q. Fletcher, Gold Bull. 43 (2010) 298-306.

[8] M. Pan, A. J. Brush, Z. D. Pozun, H. C. Ham, W.-Y. Yu, G. Henkelman, G. S. Hwang, C. B. Mullins, Chem. Soc. Rev. 42 (2013) 5002-5013.

[9] A. Corma, P. Serna, H. García, J. Am. Chem. Soc. 129 (2007) 6358-6359.

[10] A. Taketoshi, M. Haruta, Chem. Lett. 43 (2014) 380-387.

[11] M. Okumura, T. Akita, M. Haruta, Catal. Today 74 (2002) 265-269.

[12] X. Wang, N. Perret, M. A. Keane, Appl. Catal. A: Gen. 467 (2013) 575-584.

[13] R. Zanella, C. Louis, S. Giorgio, R. Touroude, J. Catal. 223 (2004) 328-339.

[14] U. Hartfelder, C. Kartusch, M. Makosch, M. Rovezzi, J. Sa, J. A. van Bokhoven, Catal. Sci. Technol. 3 (2013) 454-461.

[15] C. Milone, R. Ingoglia, L. Schipilliti, C. Crisafulli, G. Neri, S. Galvagno, J. Catal. 236 (2005) 80-90.

[16] H. Rojas, G. Díaz, J. J. Martínez, C. Castañeda, A. Gómez-Cortés, J. Arenas-Alatorre, J. Mol. Catal. A: Chem. 363-364 (2012) 122-128.

[17] M. Boronat, P. Concepción, A. Corma, S. González, F. Illas, P. Serna, J. Am. Chem. Soc. 129 (2007) 16230-16237.

[18] K. Shimizu, Y. Miyamoto, T. Kawasaki, T. Tanji, Y. Tai, A. Satsuma, J. Phys. Chem. C 113 (2009) 17803-17810.

[19] X. Wang, N. Perret, J. J. Delgado, G. Blanco, X. Chen, C. M. Olmos, S. Bernal, M. A. Keane, J. Phys. Chem. C 117 (2013) 994-1005. 
[20] F. Cárdenas-Lizana, S. Gómez-Quero, L. Kiwi-Minsker, M. A. Keane, Int. J. Nanotech. 9 (2012) 92-112.

[21] N. Perret, F. Cárdenas-Lizana, D. Lamey, V. Laporte, L. Kiwi-Minsker, M. A. Keane, Top. Catal. 55 (2012) 955-968.

[22] G. C. Bond, Molecules 17 (2012) 1716-1743.

[23] M. Li, X. Wang, N. Perret, M. A. Keane, Catal. Commun. 46 (2014) 187-191.

[24] J. Lenz, B. C. Campo, M. Alvarez, M. A. Volpe, J. Catal. 267 (2009) 50-56.

[25] X. Zhang, H. Shi, B.-Q. Xu, J. Catal. 279 (2011) 75-87.

[26] G. Jacobs, T. K. Das, Y. Zhang, J. Li, G. Racoillet, B. H. Davis, Appl. Catal. A: Gen. 233 (2002) 263-281.

[27] B. Campo, C. Petit, M. A. Volpe, J. Catal. 254 (2008) 71-78.

[28] L. Delannoy, N. Weiher, N. Tsapatsaris, A. M. Beesley, L. Nchari, S. L.M. Schroeder, C. Louis, Top. Catal. 44 (2007) 263-273.

[29] M. Ousmane, L. F. Liotta, D. di Carlo, G. Pantaleo, A. M. Venezia, G. Deganello, L. Retailleau, A. Boreave, A. Giroir-Fendler, Appl. Catal. B: Environ. 101 (2011) 629-637.

[30] F. Arena, P. Famulari, G. Trunfio, G. Bonura, F. Frusteri, L. Spadaro, Appl. Catal. B: Environ. 66 (2006) 81-91.

[31] D. Andreeva, V. Idakiev, T. Tabakova, L. Ilievaa, P. Falaras, A. Bourlinos, A. Travlos, Catal. Today 72 (2002) 51-57.

[32] G. Jacobs, S. Ricote, P. M. Patterson, U. M. Graham, A. Dozier, S. Khalid, E. Rhodus, B. H. Davis, Appl. Catal. A: Gen. 292 (2005) 229-243.

[33] S. Scirè, C. Crisafulli, S. Minicò, G. G. Condorelli, A. Di Mauro, J. Mol. Catal. A: Chem. 284 (2008) 24-32.

[34] R. Prins, Chem. Rev. 112 (2012) 2714-2738.

[35] C. Amorim, M. A. Keane, J. Hazard. Mater. 211-212 (2012) 208-217.

[36] K.-D. Jung, A. T. Bell, J. Catal. 193 (2000) 207-223.

[37] H. Ishikawa, J. N. Kondo, K. Domen, J. Phys. Chem. B 103 (1999) 3229-3234.

[38] D. Haffad, U. Kameswari, M. M. Bettahar, A. Chambellan, J. C. Lavalley, J. Catal. 172 (1997) 85-92.

[39] M. V. Ganduglia-Pirovano, A. Hofmann, J. Sauer, Surf. Sci. Rep. 62 (2007) 219-270.

[40] F. Boccuzzi, A. Chiorino, M. Manzoli, D. Andreeva, T. Tabakova, J. Catal. 188 (1999) 176185.

[41] T. Tabakova, F. Boccuzzi, M. Manzoli, D. Andreeva, Appl. Catal. A: Gen. 252 (2003) 385397.

[42] T. Tabakova, G. Avgouropoulos, J. Papavasiliou, M. Manzoli, F. Boccuzzi, K. Tenchev, F. Vindigni, T. Ioannides, Appl. Catal. B: Environ. 101 (2011) 256-265.

[43] G. C. Bond, C. Louis, D. T. Thompson, Catalysis by Gold, Imperial College Press, London, 
2006.

[44] G. L. Haller, D. E. Resasco, Adv. Catal. 36 (1989) 173-235.

[45] C. Mohr, H. Hofmeister, P. Claus, J. Catal. 213 (2003) 86-94.

[46] L. F. Liotta, G. Pantaleo, F. Puleo, A. M. Venezia, Catal. Today 187 (2012) 10-19.

[47] N. Perret, X. Wang, L. Delannoy, C. Potvin, C. Louis, M. A. Keane, J. Catal. 286 (2012) $172-$ 183.

[48] F. Moreau, G. C. Bond, A. O. Taylor, J. Catal. 231 (2005) 105-114.

[49] S. Arrii, F. Morfin, A. J. Renouprez, J. L. Rousset, J. Am. Chem. Soc. 126 (2004) 1199-1205.

[50] S. Schimpf, M. Lucas, C. Mohr, U. Rodemerck, A. Brückner, J. Radnick, H. Hofmeister, P. Claus, Catal. Today 72 (2002) 63-78.

[51] A. M. Visco, F. Neri, G. Neri, A. Donato, C. Milone, S. Galvagno, Phys. Chem. Chem. Phys. 1 (1999) 2869-2873.

[52] Y.-F. Han, Z. Zhong, K. Ramesh, F. Chen, L. Chen, T. White, Q. Tay, S. N. Yaakub, Z. Wang, J. Phys. Chem. C 111 (2007) 8410-8413.

[53] W. Deng, A. I. Frenkel, R. Si, M. Flytzani-Stephanopoulos, J. Phys. Chem. C 112 (2008) 12834-12840.

[54] A. N. Pestryakov, V. V. Lunin, A. N. Kharlanov, D. I. Kochubey, N. Bogdanchikova, A. Yu. Stakheev, J. Mol. Struct. 642 (2002) 129-136.

[55] S. Peters, S. Peredkov, M. Neeb, W. Eberhardt, M. Al-Hada, Surf. Sci. 608 (2013) 129-134.

[56] A. Saadi, Z. Rassoul, M. M. Bettahar, J. Mol. Catal. A: Chem. 164 (2000) 205-216.

[57] A. Saadi, R. Merabti, Z. Rassoul, M. M. Bettahar, J. Mol. Catal. A: Chem. 253 (2006) 79-85.

[58] M. Chen, D. W. Goodman, Acc. Chem. Res. 39 (2006) 739-746.

[59] P. Claus, A. Brückner, C. Mohr, H. Hofmeister, J. Am. Chem. Soc. 122 (2000) 11430-11439.

[60] M. Arai, A. Obata, Y. Nishiyama, React. Kinet. Catal. Lett. 61 (1997) 275-280.

[61] C. T. Campbell, C. H. F. Peden, Science 309 (2005) 713-714.

[62] C. Milone, C. Crisafulli, R. Ingoglia, L. Schipilliti, S. Galvagno, Catal. Today 122 (2007) 341-351.

[63] M. A. Keane, J. Mol. Catal. A: Chem. 118 (1997) 261-269.

[64] M. A. Vannice, D. Poondi, J. Catal. 169 (1997) 166-175.

[65] H. He, H. X. Dai, L. H. Ng, K. W. Wong, C. T. Au, J. Catal. 206 (2002) 1-13.

[66] J. A. Rodriguez, S. Ma, P. Liu, J. Hrbek, J. Evans, M. Pérez, Science 318 (2007) 1757-1760.

[67] T.-J. Huang, H.-J. Lin, T.-C. Yu, Catal. Lett. 105 (2005) 239-247.

[68] C. Doornkamp, V. Ponec, J. Mol. Catal. A: Chem. 162 (2000) 19-32.

[69] A. Sepúlveda-Escribano, F. Coloma, F. Rodríguez-Reinoso, J. Catal. 178 (1998) 649-657.

[70] S. Sitthisa, T. Sooknoi, Y. Ma, P. B. Balbuena, D. E. Resasco, J. Catal. 277 (2011) 1-13.

[71] N. Perret, X. Wang, T. Onfroy, C. Calers, M. A. Keane, J. Catal. 309 (2014) 333-342.

[72] A. Maltha, S. C. van Wermeskerken, T. L. F. Favre, P. Angevaare, E. J. Grootendorst, C. A. 
Koutstaal, A. P. Zuur, V. Ponec, Catal. Today 10 (1991) 387-391. 
Table 1: Gold loading, specific surface area (SSA), pore volume, Au particle size from TEM/STEM analysis (d), $\mathrm{H}_{2}$ consumption during temperature programmed reduction (TPR) and requirements for reduction of the $\mathrm{Au}$ precursor, $\mathrm{H}_{2}$ and $\mathrm{O}_{2}$ chemisorption (post-TPR), $\mathrm{H}_{2}$ released during temperature programmed desorption (TPD), support point of zero charge $\left(\mathrm{pH}_{\mathrm{pzc}}\right), \mathrm{Au} 4 f_{7 / 2}$ binding energy $(\mathrm{BE})$ and standard redox potential $\left(E_{\text {redox }}\right)$ of the supports.

\begin{tabular}{|c|c|c|c|c|c|c|c|c|c|c|c|}
\hline Catalyst & $\begin{array}{c}\text { Au loading } \\
(\% \mathrm{w} / \mathrm{w})\end{array}$ & $\begin{array}{c}\text { SSA } \\
\left(\mathrm{m}^{2} \mathrm{~g}^{-1}\right)\end{array}$ & $\begin{array}{l}\text { Pore volume } \\
\qquad\left(\mathrm{cm}^{3} \mathrm{~g}^{-1}\right)\end{array}$ & $\begin{array}{c}d \\
(\mathrm{~nm})\end{array}$ & $\begin{array}{l}\text { TPR H} 2 \text { consumption } \\
\left(\mu \mathrm{mol} \mathrm{g}{ }^{-1}\right)\end{array}$ & $\begin{array}{c}\mathrm{H}_{2} \\
\text { chemisorption } \\
\left(\mu \mathrm{mol} \mathrm{g}_{\mathrm{Au}}^{-1}\right)\end{array}$ & $\begin{array}{l}\mathrm{H}_{2} \text { desorbed } \\
\left(\mathrm{mmol} \mathrm{gAu}^{-1}\right)\end{array}$ & $\begin{array}{c}\mathrm{O}_{2} \\
\text { chemisorption } \\
\left(\mu \mathrm{mol} \mathrm{g}{ }^{-1}\right)\end{array}$ & $\mathrm{pH}_{\mathrm{pzc}}$ & $\begin{array}{c}\mathrm{Au} 4 f_{7 / 2} \mathrm{BE} \\
(\mathrm{eV})\end{array}$ & $\begin{array}{c}E_{\text {redox }} \\
(\mathrm{V})\end{array}$ \\
\hline $\mathrm{Au} / \gamma-\mathrm{Al}_{2} \mathrm{O}_{3}$ & 1.1 & 166 & 0.36 & 4.3 & $87^{\mathrm{a}} / 84^{\mathrm{b}}$ & 318 & 51 & 1 & 7.1 & 83.3 & -1.7 \\
\hline $\mathrm{Au} / \mathrm{TiO}_{2}$ & 1.3 & 44 & 0.12 & 4.5 & $126^{\mathrm{a} / 91^{\mathrm{b}}}$ & 162 & 9 & 5 & 6.7 & 83.5 & -0.6 \\
\hline $\mathrm{Au} / \mathrm{ZrO}_{2}$ & 1.0 & 93 & 0.13 & 7.0 & $56^{\mathrm{a}} / 61^{\mathrm{b}}$ & 137 & 28 & 3 & 7.4 & 83.6 & -1.5 \\
\hline $\mathrm{Au} / \mathrm{CeO}_{2}$ & 3.0 & 108 & 0.15 & 2.0 & $553^{\mathrm{a} / 231^{\mathrm{b}}}$ & 58 & 6 & 132 & 6.8 & 84.7 & 1.6 \\
\hline $\mathrm{Au} / \alpha-\mathrm{Fe}_{2} \mathrm{O}_{3}$ & 1.2 & 57 & 0.16 & 2.6 & $750^{\mathrm{a}} / 93^{\mathrm{b}}$ & 72 & 4 & 168 & 8.1 & 84.2 & 0.8 \\
\hline $\mathrm{Au} / \mathrm{Fe}_{3} \mathrm{O}_{4}$ & 0.9 & 11 & 0.02 & 7.6 & $500^{\mathrm{a}} / 90^{\mathrm{b}}$ & $<1$ & $<1$ & 58 & 5.8 & 84.1 & 0.1 \\
\hline
\end{tabular}

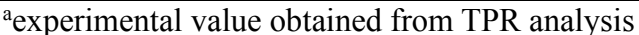

calculated value for $\mathrm{Au}^{3+} \rightarrow \mathrm{Au}^{0}$ 
Table 2: Effect of reaction temperature on turnover frequency (TOF) and product selectivity $\left(S_{\mathrm{j}}\right)$ for the conversion of benzaldehyde over $\mathrm{Au} / \gamma-\mathrm{Al}_{2} \mathrm{O}_{3}$, $\mathrm{Au} / \mathrm{Fe}_{3} \mathrm{O}_{4}$ and $\mathrm{Au} / \mathrm{CeO}_{2}$.

\begin{tabular}{cccccc}
\hline Catalyst & $\begin{array}{c}T \\
(\mathrm{~K})\end{array}$ & $\begin{array}{c}\text { TOF } \\
\left(\mathrm{h}^{-1}\right)\end{array}$ & $\begin{array}{c}\text { Sbenzene } \\
(\%)\end{array}$ & $\begin{array}{c}S_{\text {toluene }} \\
(\%)\end{array}$ & $\begin{array}{c}\text { S benzyl alcohol } \\
(\%)\end{array}$ \\
\hline & 413 & 82 & 0 & 0 & 100 \\
$\mathrm{Au} / \gamma-\mathrm{Al}_{2} \mathrm{O}_{3}$ & 473 & 126 & 0 & 70 & 30 \\
& 573 & 258 & 71 & 21 & 8 \\
& 413 & $\mathrm{a}$ & - & - & - \\
$\mathrm{Au} / \mathrm{Fe}_{3} \mathrm{O}_{4}$ & 473 & 192 & 10 & 90 & 0 \\
& 573 & 378 & 21 & 79 & 0 \\
\hline $\mathrm{Au} / \mathrm{CeO}_{2}$ & 473 & 8 & - & - & - \\
& 573 & 49 & 20 & 80 & 0 \\
\hline
\end{tabular}

${ }^{\mathrm{a}}$ no detectable activity 
Table 3: Benzyl alcohol turnover frequency (TOF) and product selectivity $\left(S_{\mathrm{j}}\right)$ for reaction over $\mathrm{Au} / \mathrm{Fe}_{3} \mathrm{O}_{4}$ and $\mathrm{Au} / \mathrm{CeO}_{2}: T=573 \mathrm{~K}$.

\begin{tabular}{ccccc}
\hline Catalyst & $\begin{array}{c}\text { TOF } \\
\left(\mathrm{h}^{-1}\right)\end{array}$ & $\begin{array}{c}S_{\text {benzene }} \\
(\%)\end{array}$ & $\begin{array}{c}S_{\text {toluene }} \\
(\%)\end{array}$ & $\begin{array}{c}S_{\text {benzaldehyde }} \\
(\%)\end{array}$ \\
\hline $\mathrm{Au} / \mathrm{Fe}_{3} \mathrm{O}_{4}$ & 364 & 0 & 95 & 5 \\
$\mathrm{Au} / \mathrm{CeO}_{2}$ & 17 & 8 & 17 & 75 \\
\hline
\end{tabular}




\section{Figure captions}

Fig.1: Temperature programmed reduction (TPR) profiles for (I) supported Au (solid lines) and (II) the corresponding supports (dotted lines): (A) $\gamma-\mathrm{Al}_{2} \mathrm{O}_{3}$, (B) $\mathrm{TiO}_{2}$, (C) $\mathrm{ZrO}_{2}$, (D) $\mathrm{CeO}_{2}, \mathbf{( E )} \alpha-\mathrm{Fe}_{2} \mathrm{O}_{3}, \mathbf{( F )} \mathrm{Fe}_{3} \mathrm{O}_{4}$.

Fig. 2: Hydrogen temperature programmed desorption (TPD) profiles: (A) $\mathrm{Au} / \gamma-\mathrm{Al}_{2} \mathrm{O}_{3}$, (B) $\mathrm{Au} / \mathrm{TiO}_{2}$, (C) $\mathrm{Au} / \mathrm{ZrO}_{2}$, (D) $\mathrm{Au} / \mathrm{CeO}_{2}$, (E) $\mathrm{Au} / \alpha-\mathrm{Fe}_{2} \mathrm{O}_{3}$, (F) $\mathrm{Au} / \mathrm{Fe}_{3} \mathrm{O}_{4}$.

Fig. 3: XRD patterns for activated/passivated (A) $\mathrm{Au} / \gamma-\mathrm{Al}_{2} \mathrm{O}_{3}$, (B) $\mathrm{Au} / \mathrm{TiO}_{2}$, (C) $\mathrm{Au} / \mathrm{ZrO} \mathrm{r}_{2}$, (D) $\mathrm{Au} / \mathrm{CeO}_{2}$, (E) $\mathrm{Au} / \alpha-\mathrm{Fe}_{2} \mathrm{O}_{3}$ and (F) $\mathrm{Au} / \mathrm{Fe}_{3} \mathrm{O}_{4}$; reference JCPDS-ICDD patterns (see card No. in section 2.2) are included for $\mathrm{Au}, \boldsymbol{\gamma}-\mathrm{Al}_{2} \mathrm{O}_{3}$, anatase $\mathrm{TiO}_{2}\left(\mathrm{~A}-\mathrm{TiO}_{2}\right)$, rutile $\mathrm{TiO}_{2}\left(\mathrm{R}-\mathrm{TiO}_{2}\right)$, monoclinic $\mathrm{ZrO}_{2}(\mathrm{M}-\mathrm{ZrO} 2)$, tetragonal $\mathrm{ZrO}_{2}\left(\mathrm{~T}-\mathrm{ZrO}_{2}\right), \mathrm{CeO}_{2}, \alpha-\mathrm{Fe}_{2} \mathrm{O}_{3}$ (hematite) and $\mathrm{Fe}_{3} \mathrm{O}_{4}$ (magnetite).

Fig. 4: Representative TEM/STEM images of (A) $\mathrm{Au} / \gamma-\mathrm{Al}_{2} \mathrm{O}_{3}$, (B) $\mathrm{Au} / \mathrm{TiO}_{2}$, (C) $\mathrm{Au} / \mathrm{ZrO}_{2}$, (D) $\mathrm{Au} / \mathrm{CeO}_{2}$, (E) $\mathrm{Au} / \alpha-\mathrm{Fe}_{2} \mathrm{O}_{3}$ and (F) $\mathrm{Au} / \mathrm{Fe}_{3} \mathrm{O}_{4}$ with associated $\mathrm{Au}$ size distribution histograms.

Fig. 5: XPS spectra over the $\mathrm{Au} 4 f$ region for (A) $\mathrm{Au} / \gamma-\mathrm{Al}_{2} \mathrm{O}_{3}$, (B) $\mathrm{Au} / \mathrm{TiO}_{2}$, (C) $\mathrm{Au} / \mathrm{ZrO}{ }_{2}$, (D) $\mathrm{Au} / \mathrm{CeO}_{2}$, (E) $\mathrm{Au} / \alpha-\mathrm{Fe}_{2} \mathrm{O}_{3}$ and (F) $\mathrm{Au} / \mathrm{Fe}_{3} \mathrm{O}_{4}$; experimental data are given by $\mathbf{m}$ were lines represent data fitting with peak deconvolution.

Fig. 6: Dependence of $\mathrm{Au} 4 f_{7 / 2}$ binding energy (BE) on the standard redox potential ( $\left.E_{\text {redox }}\right)$ of the oxide supports: (A) $\mathrm{Au} / \gamma-\mathrm{Al}_{2} \mathrm{O}_{3} ;$ (B)

$\mathrm{Au} / \mathrm{TiO}_{2} ;(\mathbf{C})$ $\mathrm{Au} / \mathrm{ZrO}_{2} ;$ (D) $\mathrm{Au} / \mathrm{CeO}_{2}$ (E) $\boldsymbol{\nabla} \mathrm{Au} / \alpha-\mathrm{Fe}_{2} \mathrm{O}_{3} ;$ (F) $\boldsymbol{\mathbf { A u }} / \mathrm{Fe}_{3} \mathrm{O}_{4}$.

Fig. 7: (I) Benzaldehyde $\left(T=413 \mathrm{~K}, n / F=1.2 \times 10^{-3} \mathrm{~h}\right)$ and (II) nitrobenzene $(T=413 \mathrm{~K}$, $n / F=3.7 \times 10^{-3} \mathrm{~h}$ ) turnover frequency $(T O F)$ as a function of Au particle size $(d):(A)$ $\mathrm{Au} / \boldsymbol{\gamma}-\mathrm{Al}_{2} \mathrm{O}_{3} ;$ (B) $4 \mathrm{Au} / \mathrm{TiO}_{2} ;$ (C) $>\mathrm{Au} / \mathrm{ZrO}_{2} ;$ (D) $\boldsymbol{\Delta} \mathrm{Au} / \mathrm{CeO}_{2} ;$ (E) $\nabla \mathrm{Au} / \boldsymbol{\alpha}-\mathrm{Fe}_{2} \mathrm{O}_{3} ;$ (F) $\mathrm{Au} / \mathrm{Fe}_{3} \mathrm{O}_{4}$. 
Fig. 8: Dependence of turnover frequency $(T O F)$ on the standard redox potential of the oxide supports ( $E_{\text {redox }}$ from [38]) in (I) benzaldehyde and (II) nitrobenzene hydrogenation: (A) $\mathrm{Au} / \gamma-\mathrm{Al}_{2} \mathrm{O}_{3} ;(\mathbf{B}) \backslash \mathrm{Au} / \mathrm{TiO}_{2} ;$ (C) $>\mathrm{Au} / \mathrm{ZrO}_{2} ;$ (D) $\Delta \mathrm{Au} / \mathrm{CeO}_{2} ;(\mathbf{E}) \boldsymbol{\nabla} \mathrm{Au} / \boldsymbol{\alpha}-\mathrm{Fe}_{2} \mathrm{O}_{3} ;$ (F) $\mathrm{Au} / \mathrm{Fe}_{3} \mathrm{O}_{4}$.

Fig. 9: Proposed reaction mechanism for (I) benzaldehyde and (II) nitrobenzene hydrogenation over Au on reducible supports; $\mathrm{M}=\mathrm{Ce}$ or Fe.

Fig. 10: Proposed reaction mechanism for benzaldehyde hydrogenation over $\mathrm{Au} / \gamma-\mathrm{Al}_{2} \mathrm{O}_{3}(\mathrm{M}$ $=\mathrm{Al})$ at different reaction temperatures. 
Fig. 1
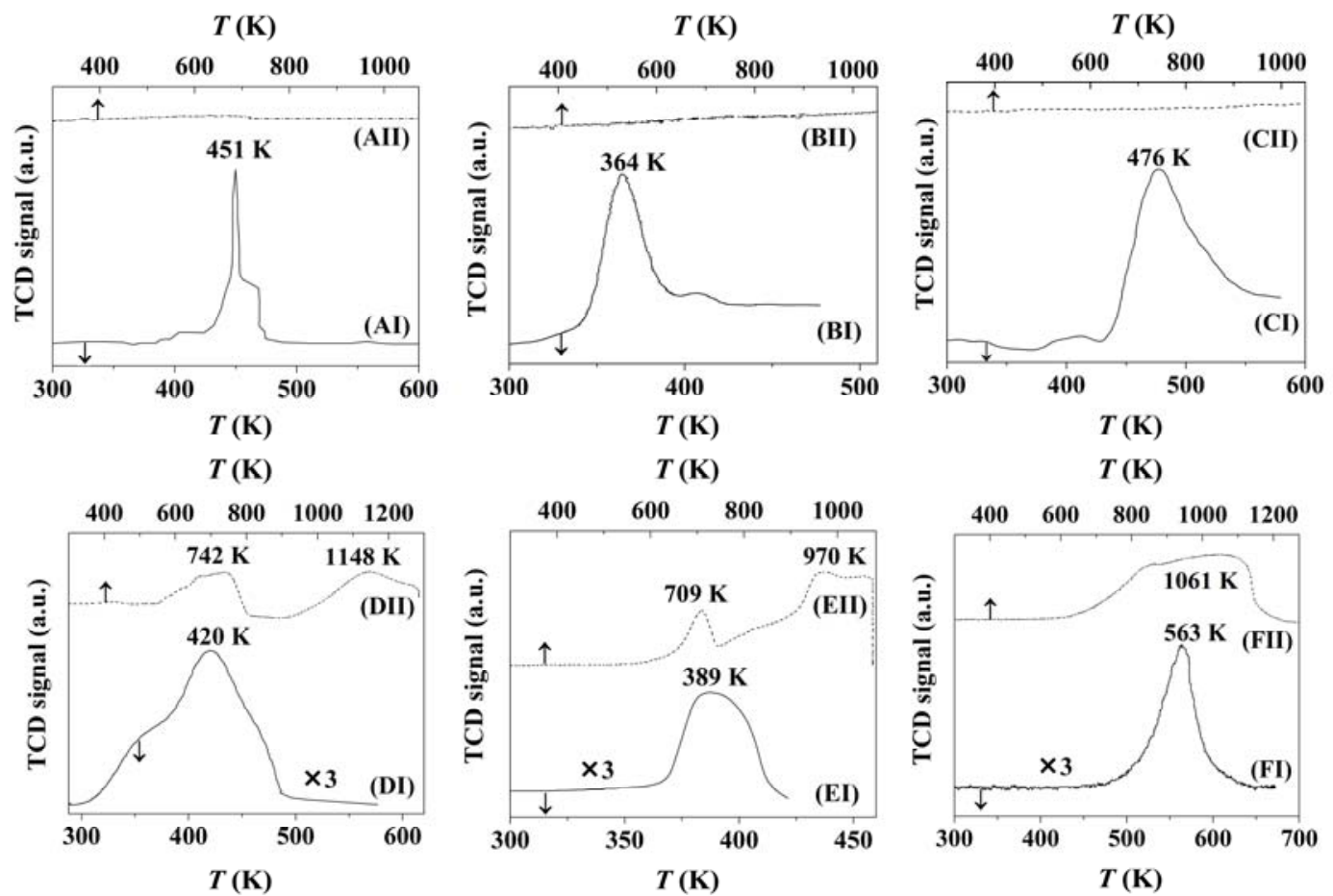
Fig. 2
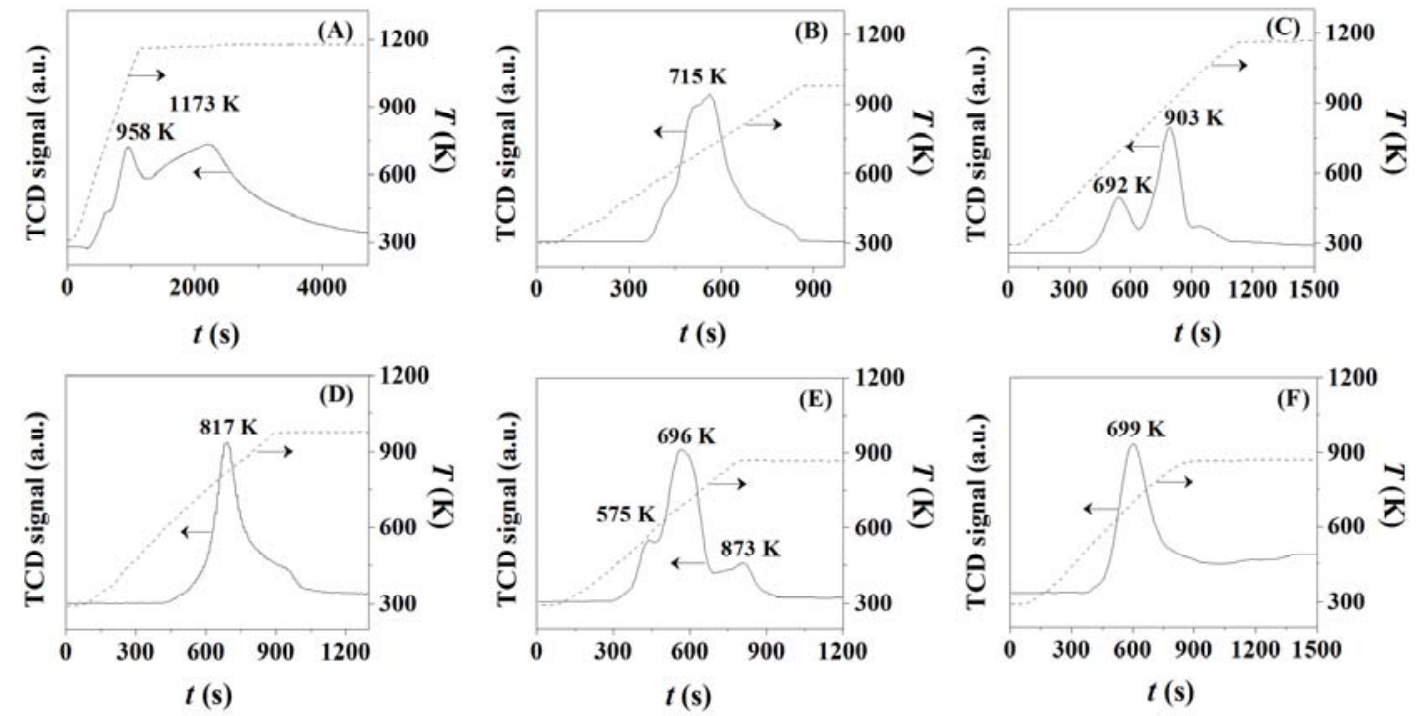
Fig. 3
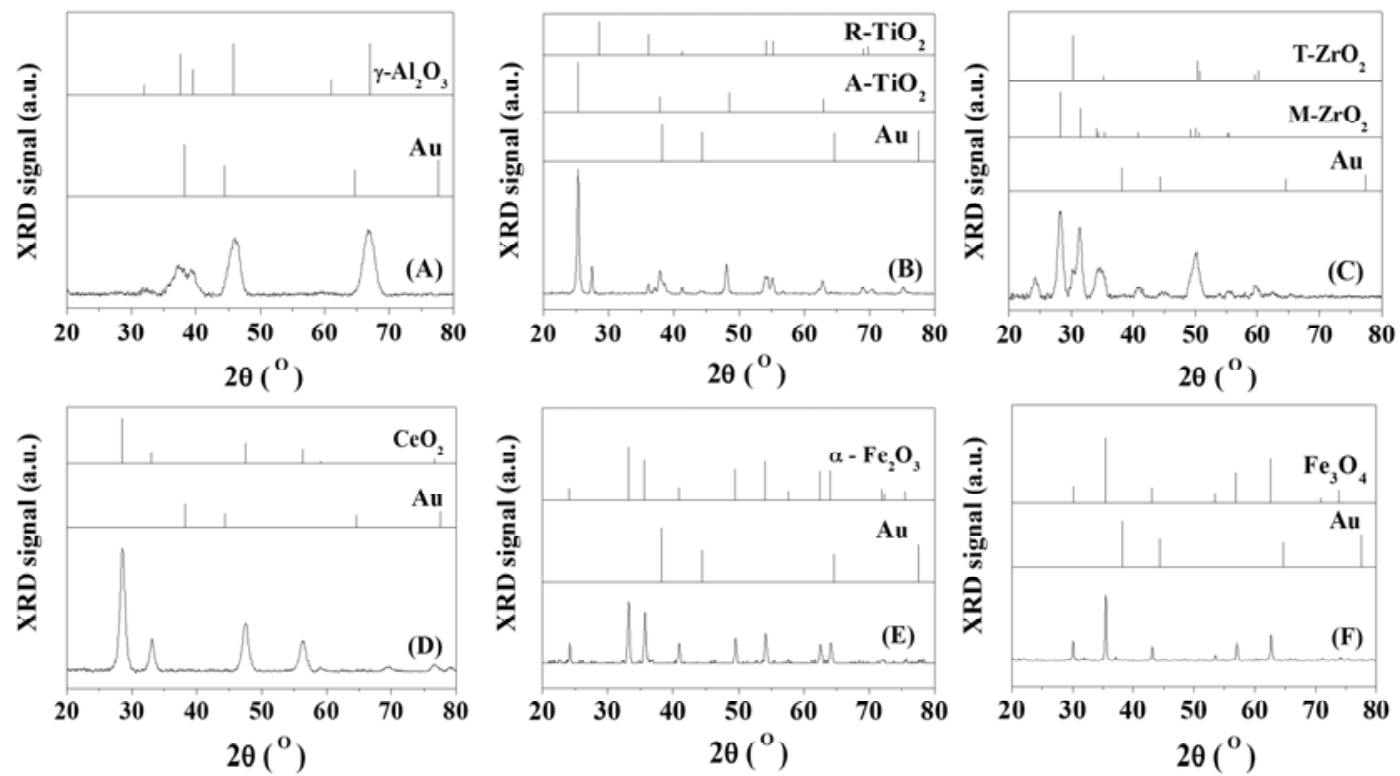
Fig. 4
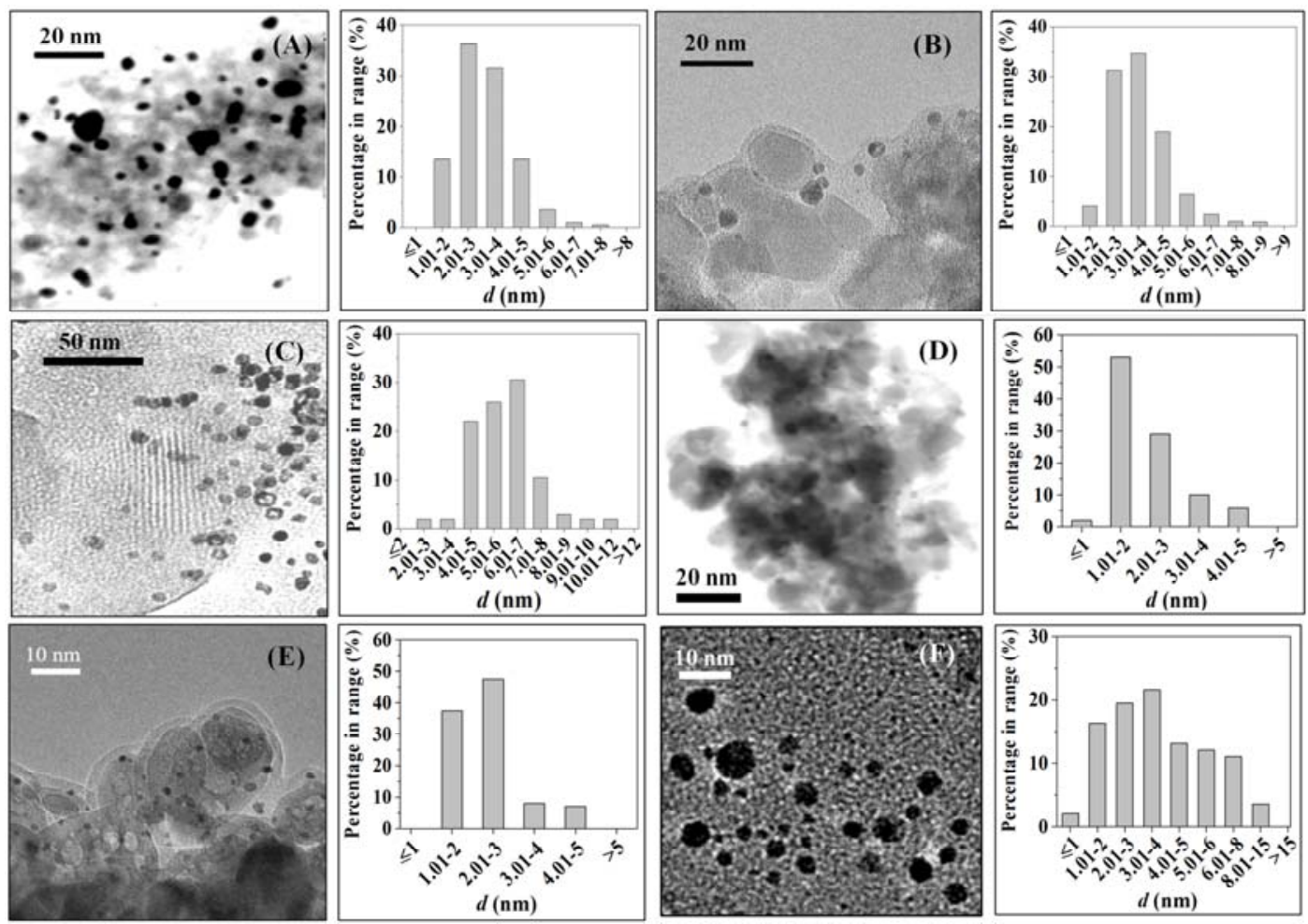
Fig. 5
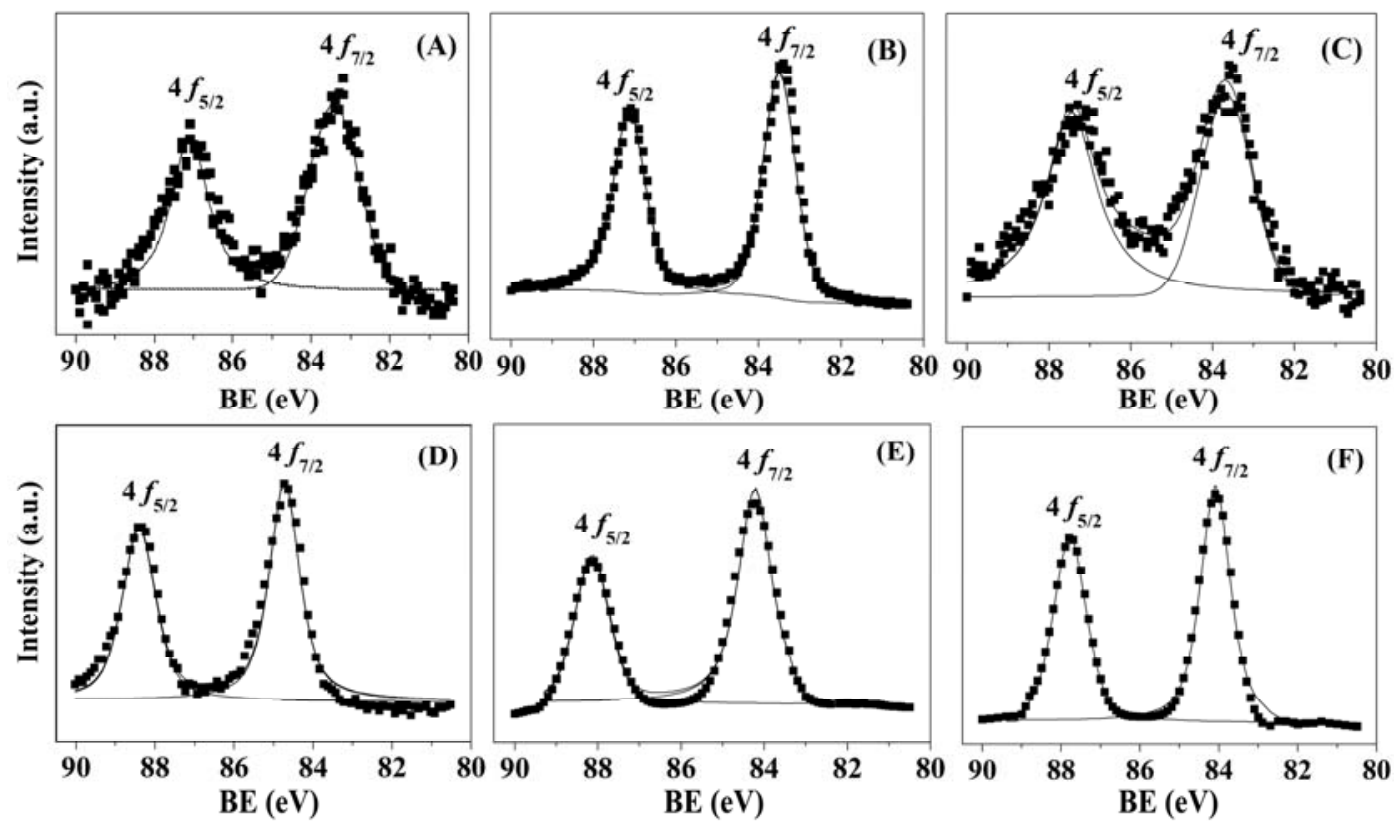
Fig. 6

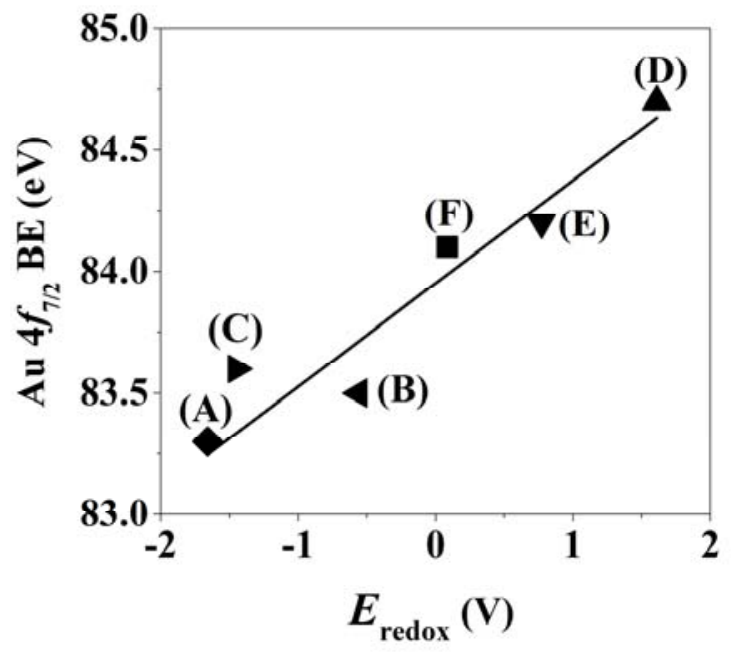


Fig. 7
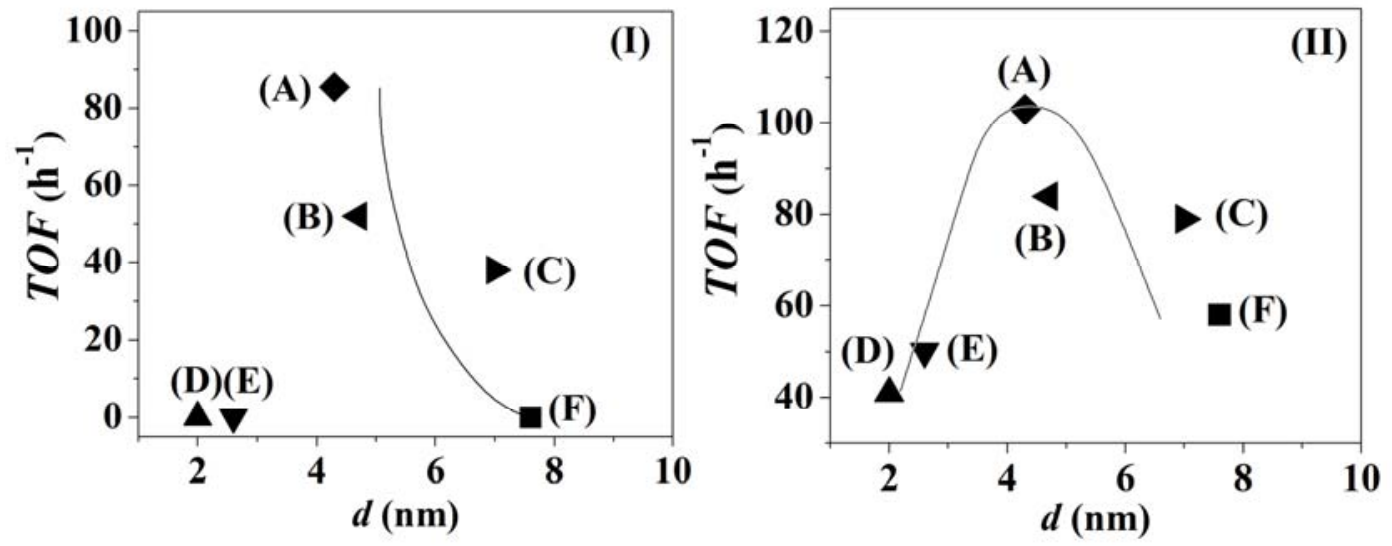
Fig. 8
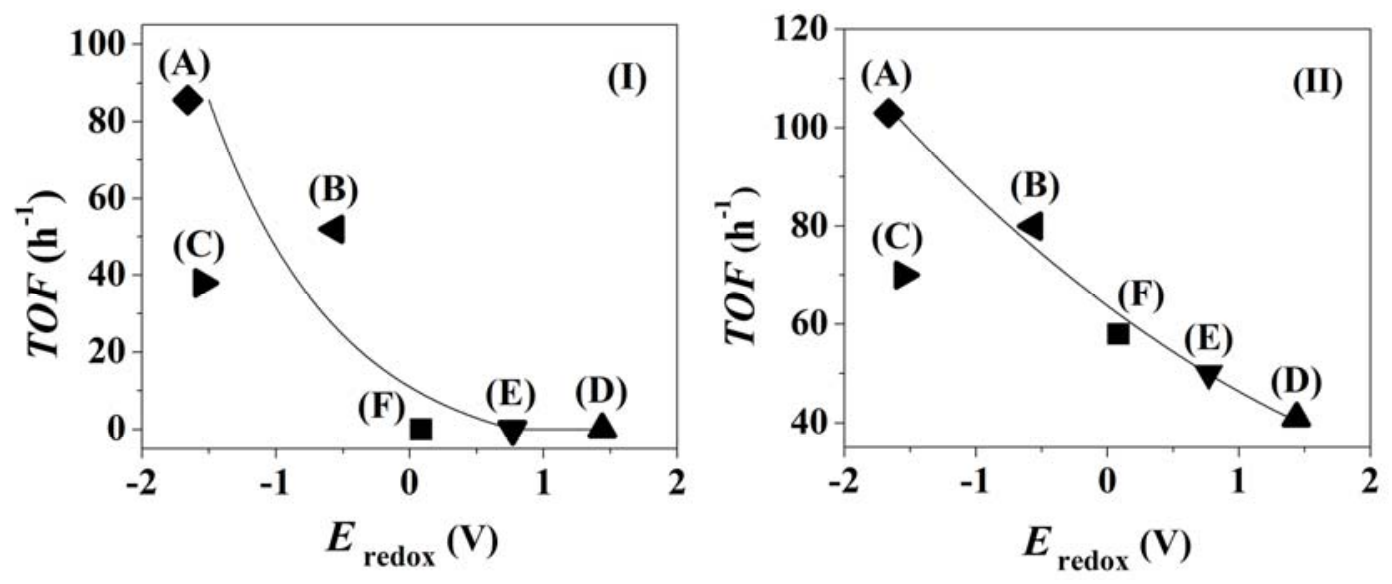
Fig. 9

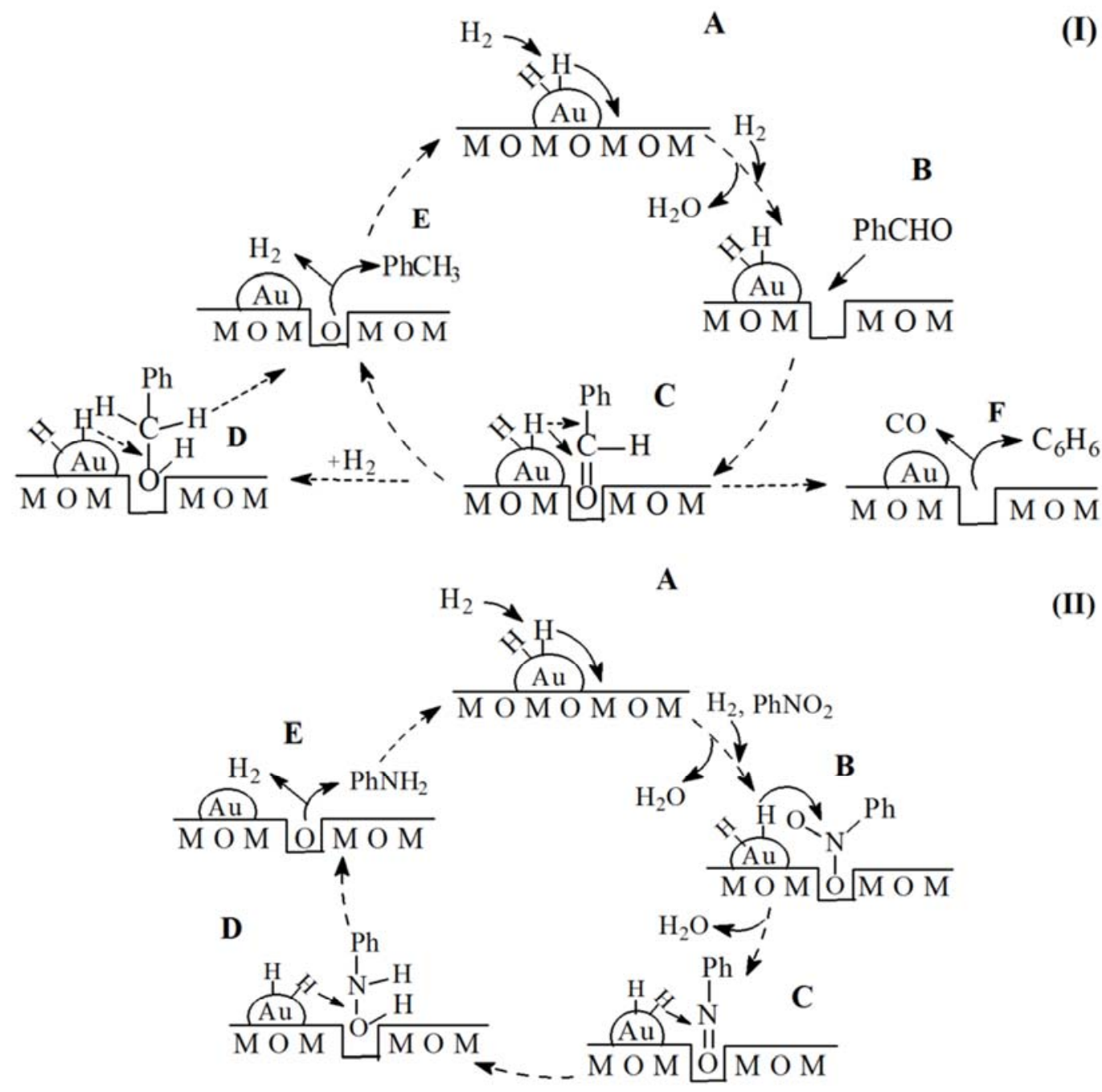


Fig. 10

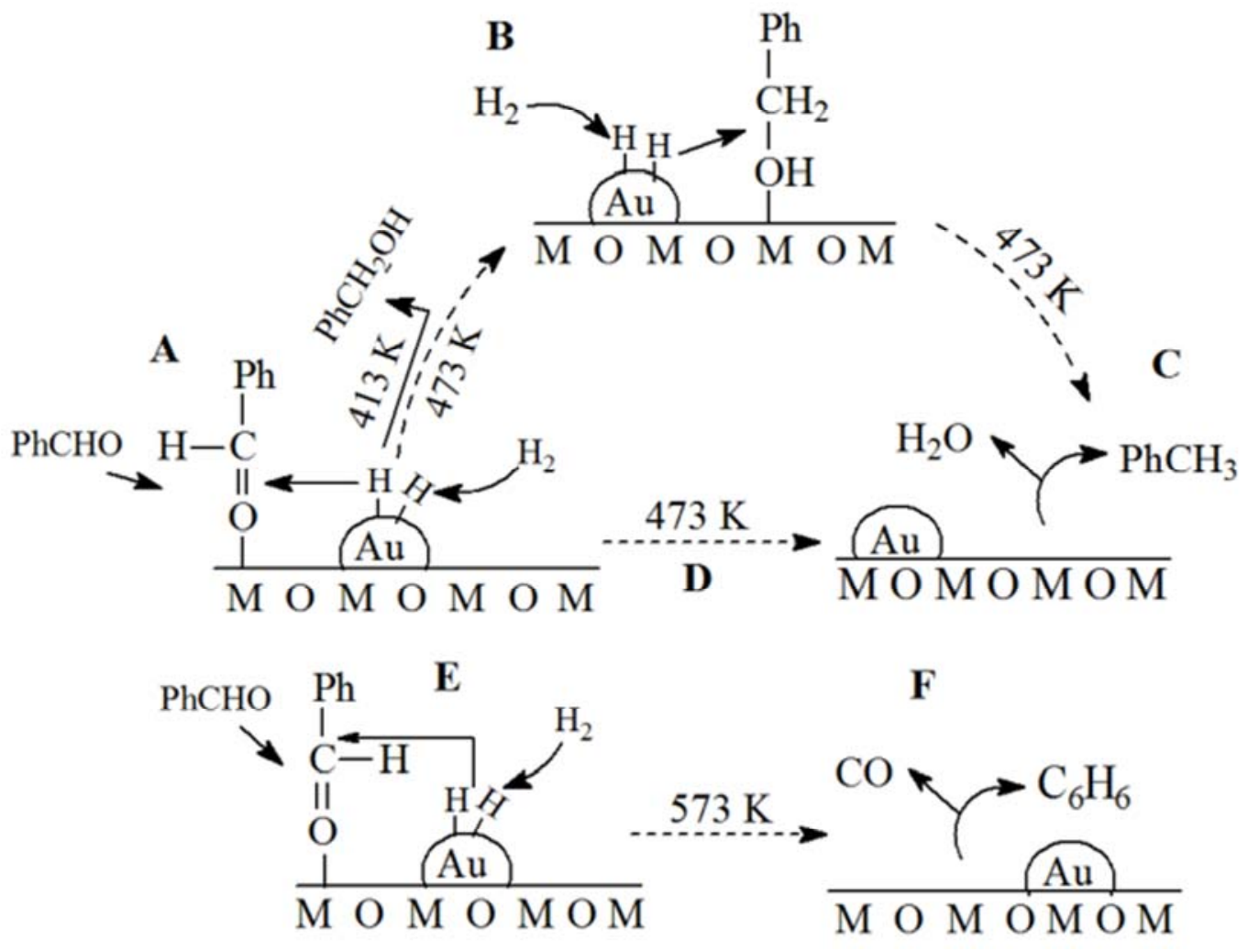

